\title{
Letterkundige en wysgerige kanttekeninge by die transformasie-trilogie van Antjie Krog
}

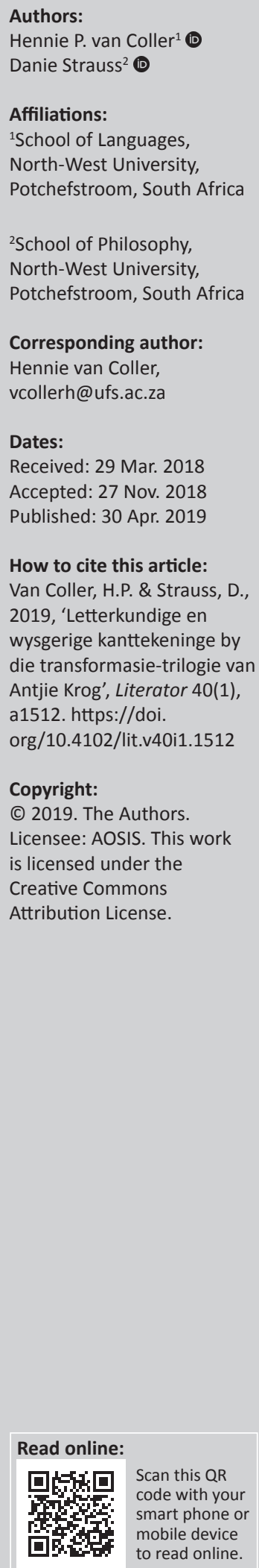

Literary and philosophical marginal notes regarding the transformation trilogy of Antjie Krog. In her published PhD thesis, 'baie worde : Identiteit en transformasie by Antjie Krog ['many becomings': Identity and transformation in the thought of Antjie Krog], Jacomien Van Niekerk directs her attention to the issues mentioned in the title of her thesis. In the discussion of the trilogy at hand a brief assessment is given of the place of works similar to these within the South African literature. The work of Van Niekerk is appreciated as a contribution to Krog studies, and as a reflection on identity within a South African context. According to Van Niekerk, the concept 'identity' and the concern for the possibility of the origination of new identities, such as a South African, Pan African and even a 'black' identity, occupies a central position in this work. The work of Van Niekerk is aligned with postcolonial thinking on identity, nationhood and becoming, as well as the investigation of 'whiteness', and 'blackness' as the opposite of the 'white' Eurocentrism of the colonial era. Van Niekerk shows that Krog understands identity as a process of becoming. According to Van Niekerk, the ultimate aim of her book is to launch an investigation into nationhood, while simultaneously highlighting Krog's rejection of Eurocentrism and the accompanying conception of the 'inherent superiority' of western modernity. A shortcoming in the work of Van Niekerk is the striking absence of references to writers such as F.A. van Jaarsveld, Fransjohan Pretorius, J.C. Steyn and Herman Giliomee, all of them authors who wrote extensively about these issues. This results in a particularly one-sided perspective on the past. Krog attempts to justify everything in terms of African thought. Her thinking often borders upon becoming superficial, emotional and ideologically driven. Sometimes it is even 'propagandistic' and non-intellectual in nature. Van Niekerk mentions the strong interest in African philosophy. However, both western philosophy and African philosophy are confronted with the same problems. In this article, attention is given to those philosophical problems that are implicit or explicit in the work of Van Niekerk. Among them are problems such as the issue of essentialism, the relationships between what is universal and what is individual, constancy and dynamics (persistence and change), the nature of the whole-parts relation, the question concerning identity-in-becoming, nation, ethnic groups and the state, the relationships between community and communality, the question regarding the assumed social constructs of human society, blackness and whiteness, and a postcolonial yearning to 'become otherwise'. Even though it may appear that these problems are not interrelated, the way in which they are scrutinised in more detail indeed makes it clear that they do cohere, apart from the fact that all these problems surface in Van Niekerk's work and in the publications of Krog. Ultimately all these problems are philosophical in nature. Investigating them does not elevate one or another 'thought-system' to become the norm for all the others. Rather attention is drawn to certain states of affairs, as well as exercising immanent criticism.

Keywords: Kanttekeninge; Jacomien van Niekerk; identiteit; transformasie; letterkunde.

\section{Inleidende opmerkings}

Dr. Jacomien van Niekerk is een van 'n groeiende groep jong akademici wat reeds opvallende bydraes gemaak het op die gebied van die Afrikaanse letterkunde. Iets wat hulle gemeen het, is goeie kennis van resente teoretiese strominge, $n$ kontekstuele aanpak waarin nie net die sosiale aspek van letterkunde voorop staan nie, maar die Afrikaanse letterkunde ook as deel van 'wêreldletterkunde' gesien word. Voorts is hulle multi- of inter-dissiplinêre benadering opvallend en word daar in hulle werk byvoorbeeld ruim aandag aan die historiese, ideologiese of filosofiese onderbou van die letterkunde bestee.

Die konkrete gevolge is dat hulle dikwels komparatisties werk en byvoorbeeld Afrikaanse, Nederlandse en Engelse tekste (maar ook kontekste soos literêre sisteme of literêre velde) met 
mekaar vergelyk. Voorts is daar soms 'n ongeduld met in vorige geslag letterkundiges merkbaar in hulle werk, omdat die eersgenoemdes die polities-ideologiese (ook ekologiese) en kontekstuele aspek van letterkunde sou verwaarloos het. Wat die Afrikaanse letterkunde betref, word ruim aandag derhalwe ook bestee aan figure soos Wilma Stockenström, Ingrid Winterbach, Marlene van Niekerk en Antjie Krog.

'baie worde': Identiteit en transformasie by Antjie Krog (2016) deur Jacomien van Niekerk is gebaseer op haar 2014-proefskrif aan die Universiteit van Pretoria, 'Om te hoort: Aspekte van identiteit in Antjie Krog se transformasie-trilogie', onder leiding van prof. Hein Willemse. Willemse was as 'persklaarmaker' (Bylaag 1), soos dit genoem word op die kolofonbladsy van die boek, skynbaar ook vir die teksversorging van hierdie publikasie verantwoordelik wat as deel ses van Van Schaik Uitgewers (Pretoria) se 'Talatala-reeks' oor die Afrikaanse taal- en letterkunde verskyn het, waarin daar reeds boeke van onder meer Elsa Nolte, Hein Willemse en Jerzy Koch verskyn het. Opvallend van hierdie reeks is die feit dat juis enigsins verwaarloosde aspekte van die Afrikaanse taal- en letterkunde voorop staan soos die rol en plek van swart skrywers in die Afrikaanse letterkunde (Hein Willemse) en die Afrikaans van die Kaapse Moslems (Achmat Davids). Hein Grebe weer bestee aandag aan ontstaansteorieë van Afrikaans wat in die verlede gemarginaliseer is en Jerzy Koch bied 'n 'alternatiewe' literatuurgeskiedenis van Afrikaans aan in die sin dat sy blik as Poolse akademikus een is van 'buite', met ruim aandag aan prosesse en teorieë buite die sentrum van die Afrikaanse letterkunde. Daarom verwag die leser van meet af aan dat Van Niekerk se werk ook geykte verwagtings sal deurbreek.

Let daarop dat Van Niekerk die titel van haar werk bondig formuleer: 'baie [W]worde' - [I]identiteit en [T] transformasie by Antjie Krog. Daarom word van die begin af na hierdie titel verwys met die akroniem WIT (sonder die bedoeling van 'n woordspeling). Die erkenning dat op die gebied van die filosofie beweeg word, nooi ook filosowe uit om vas te stel of hierdie wysgerige probleme toereikend deursien is. Dit word uitvoerig in die laaste deel van hierdie artikel gedoen. 'n Breër wysgerige en vakfilosofiese behandeling van hierdie probleme kan in Strauss (2009) gevind word.

Lesersverwagtinge berus dikwels ook op die manier waarop in publikasie deur tekste op die agterplat bekendgestel word (in der waarheid 'gereklameer' word). Prof. Willie Burger, hoof van die Departement Afrikaans aan die Universiteit van Pretoria, bestempel hierdie studie as 'ongetwyfeld ' $n$ bydrae tot Krog-studies sowel as nadenke oor identiteit [...] in die Suid-Afrikaanse konteks'. Prof. Luc Renders van die Universiteit van Hasselt in België is nog hoër gestem in sy lof wanneer hy praat van 'n uitstekende studie wat belangrike nuwe insigte in die transformasie-trilogie van Antjie Krog oplewer'. Prof. Steward van Wyk van die Universiteit van Wes-Kaapland weer noem hierdie studie (soos Antjie Krog se tekste) 'grensoorskrydend' en benadruk die multidissiplinêre benadering wanneer hy wys op die vernuftige aanwending van 'argumente en konsepte van die politieke en morele filosofie, literêre analise en kulturele studies' om 'interessante perspektiewe te bied op die betrokke tekste'. Ook 'n gerekende Krog-kenner, prof. Louise Viljoen, is uiters positief oor hierdie werk en sê op die agterplat:

Jacomien van Niekerk lewer 'n besondere bydrae tot die kritiese diskoers oor Antjie Krog se werk, nie net binne die veld van Afrikaanse literatuurstudie nie, maar ook binne die groter veld van Krog-studies op sowel nasionale as internasionale vlak.

Jacomien van Niekerk (Van Niekerk [WIT] 2016:19) ${ }^{1}$ noem Antjie Krog se drie boeke, Country of my skull (1998), A change of tongue (2003) en Begging to be black (2009) 'n samehangende transformasie-trilogie omdat aspekte van transformasie of 'wording' ('worde' in die titel van hierdie studie) daarin sentraal sou staan. Van Niekerk vestig die aandag op sekere gemene delers in die drie boeke: bemoeienis met die geskiedenis van Suid-Afrika, veral die verhoudings tussen wit en swart en die gevolge van apartheid; aandag aan die aard en toekoms van 'n nuwe, demokratiese Suid-Afrika, oftewel die nasie-in-wording; en die beklemtoning dat dit deurgaans gaan om die perspektief van 'n wit, vroulike Afrikaner. Voorop staan die begrip 'identiteit' en die vraagstelling van Krog gaan ook oor die moontlikheid van die ontstaan van nuwe identiteite soos 'n Suid-Afrikaanse, pan-Afrikaanse en selfs 'swart' identiteit.

Anthea Garman (2015:xv) verwys na Antjie Krog as 'n openbare intellektueel wat die 'oorkoepelende behoefte in Suid-Afrika' deel om 'op deurslaggewende wyse met die verlede af te reken'. Hiermee is Van Niekerk (WIT 2016:10) dit klaarblyklik eens. Die woordkeuse van Garman (én Van Niekerk) is egter veelseggend want 'afrekening' impliseer afstandname, straf, oorwinning en die voltrekking van 'n vonnis (kyk HAT:29). Daarteenoor is die Duitse term Vergängenheitsbewärtigung die manier om met die negatiewe aspekte van die verlede om te gaan. Verwerking van die verlede (kyk ook Van Coller 1997) is veel neutraler. Ook in die Waarheids-en-versoeningsverhore het 'versoening' (naas 'vergifnis' en 'amnestie') 'n belangrike plek ingeneem. Krog is meer ongeduldig: die 'gruwels van apartheid' vereis meer as boetedoening: restitusie. Dit gaan om straf en prysgawe van identiteit (wat ook taal- en rasse-identiteit veronderstel).

\section{Werkwyse en fokus}

Van Niekerk stel haar ten doel om op 'n genuanseerde wyse na Krog se transformasie-denke in die trilogie te kyk en weg te stuur van 'geykte analises' (WIT 2016:11). Die bykomende temas wat sy wil betrek, is 'ras' (wat die problematiek van 'witheid' insluit), etiek en ubuntu. Dit alles word in die konteks van veral die postkolonialisme ingebed. Daarom fokus sy ook op kwessies wat sentraal staan binne die postkoloniale denke, naamlik identiteit, nasieskap en wording. Voorts pas dit ook in van die heersende diskoerse binne hierdie denke, naamlik 'n kritiese ondersoek na 'witheid'. Vervolgens fokus Van Niekerk op Krog se verkenning van die Afrikawêreldbeeld en haar (her) waardering van 'swartheid' juis as teenpool van die 'wit' Eurosentrisme van die koloniale era.

1.Raadpleeg die rede vir hierdie afkorting asseblief die 'Inleidende opmerkings' van hierdie artikel. 


\section{Opoffering, prysgawe en restitusie}

Van Niekerk gee van meet af aan te kenne dat sy wil probeer om 'n kritiese afstand van Krog te bewaar, veral die wyse waarop sy "“swartheid" essensialiseer' (WIT 2016:12) en impliseer dat alle swart mense bewonderenswaardig is. Volgens Van Niekerk se weergawe van Krog se denke, lyk dit asof alle wit mense aandadig aan apartheid is en sy impliseer dat alle blankes derhalwe vir apartheid moet vergoed. Hieraan verwant is die verdere vraag of blankes überhaupt deel van Suid-Afrika vorm; Van Niekerk praat in hierdie verband van die Deleuziaanse opvatting van mineurwording, wat 'sal beteken om soos die meerderheid te word' (WIT 2016:13) en haar slotsom is dat identiteit by Krog 'n wordingsproses is.

Bogenoemde kwessies het in die afgelope jare op verskeie fronte na vore getree soos in J.M. Coetzee se roman Disgrace (1999) verwoord. In wese gaan dit om die vraag oor boetedoening en by uitbreiding, restitusie. Wat moet die 'skuldige' blanke opoffer om in die nuwe, demokratiese Suid-Afrika aanvaar te word? (Kyk ook McGonegal 2009; Tantrigoda 2016; Wang 2009; Willoughby-Herald 2014a; 2014b; 2014c; 2015 - hoewel ons nie in die huidige konteks dieper daarop kan ingaan nie.) In Coetzee se roman is die implikasie dat Lucy se verkragting deel is van hierdie prysgawe en bykans as offer gesien moet word. Uitsprake van dr. Wilhelm Verwoerd (kleinseun van die eertydse 'argitek van apartheid' en Eerste Minister, dr. H.F. Verwoerd) en prof. Anton van Niekerk in Mei 2015 by die verwydering van 'n plaat wat die oud-eersteminister gehuldig het, bevestig die idee van boetedoening.

'n Mens ontkom nie aan die gevoel dat alle ou vorms van identiteit, naamlik kleur (ras), taal en besit klaarblyklik opgeoffer moet word nie. Die feit dat Coetzee self kort na die publikasie van sy roman na Australië emigreer, kan as bevestiging van so ' $n$ interpretasie gesien word. Sommige Suid-Afrikaners sien die prysgawe van Afrikaans, Afrikaneridentiteit en toenemend ook die prysgawe van eiendomsreg, as deel van die offer soos met die huidige debat oor grondonteiening sonder vergoeding blyk. Max du Preez beskuldig juis vir Krog vanweë haar 'identiteitsmoord' (WIT 2016:109). Krog se uitsprake (en Van Niekerk se kommentaar daarop) is derhalwe van aktuele belang; selfs vir die voortbestaan van die blanke (veral Afrikaanssprekende) in Suid-Afrika.

In Krog se eie poësie het sy reeds met Kleur kom nooit alleen nie (2000) begin met wat die 'uitholling' van die standaardvariëteit van Afrikaans genoem kan word (kyk Van Coller \& Odendaal 2003a; 2003b; 2007; Taljaard 2010). Hierdie procedé word meermale in verband gebring juis met afstandneming van die wit Afrikaner wat geassosieer word met standaardafrikaans en dit gaan derhalwe ook oor die aanname van 'n nuwe identiteit: verkapping van die taal druk daarom wording uit. Ook in die bundel, Mede-wete (2014), bekroon met die Hertogprys, skep sy veral deur morfologiese verkapping in wese nuwe woorde (en derhalwe 'n 'nuwe' taal). Antjie Krog se taaleksperimente gaan waarskynlik na die Joods-Duitse digter Paul Celan, wie se morfologiese verkapping van Duits eintlik 'n manier was om 'n 'onderdrukkerstaal' te omvorm en iets medemensliks daaruit te kry. ${ }^{2}$

In haar niefiksie staan taal weer eens voorop deurdat Krog (óók weens pragmatiese oorwegings) die drieluik in Engels publiseer, hoewel 'elk van die drie tekste ten minste gedeeltelik in Afrikaans ontstaan het' (WIT 2016:13). ${ }^{3}$ Van Coller and Odendaal (2007) het reeds daarop gewys dat daar by Krog die strewe is om haar voor te stel (te profileer) as Afrikaanse én Engelse skrywer en dat hierdie posisie-inname binne die groter Suid-Afrikaanse literêre veld iets sinjaleer van wat sy as skrywer beoog. Die publikasie in Engels stempel Krog nie net as óók 'n Engelse skrywer nie, maar as iemand wat die Afrikaners ook in hierdie nie-fiksie publikasies as't ware van ' $n$ afstand betrag. In baie besprekings van byvoorbeeld Country of my skull is die feit dat Krog dit in Engels gepubliseer het, trouens gesien as 'n manier om haar openlik van Afrikaans en Afrikaners te distansieer (WIT:18). Van Niekerk (WIT:15) merk ook op dat 'n ander rede vir Krog se keuse om in Engels te skryf, is om aan 'globale diskoerse oor boetedoening' deel te neem. Van Niekerk se opmerking is pejoratief soos 'aangryp' en 'kultuurindustrie', duidelik aantoon:

Wat Krog egter 'n uitsonderlike figuur maak, is die wyse waarop haar reaksie op die regimeverandering in Suid-Afrika verskil van Afrikaners wat die diskoers oor minderheidsregte aangryp, of hulle beywer vir die Afrikaanse kultuurindustrie. (WIT:15)

In 'n akademiese diskoers verwag 'n mens ten minste objektiewe beredenering hiervan. Van Wyk Louw (1939:15) het reeds getwyfel of 'kultuur in enige land ter wêreld soseer 'n saak vir organisasie is'. Tog voeg hy daaraan toe: 'En tog is hierdie eienaardige ontwikkeling by ons noodsaaklik', juis ook vanweë die oormag van Engels. Vir Krog egter, is 'die weerloosheid van Afrikaans in ná-1994 Suid-Afrika [...] juis n wins' (WIT:16).

\section{Krog en verskillende opvattings van nasieskap}

Die eintlike doel van Van Niekerk se boek is 'n ondersoek na Krog se opvatting van nasieskap. Volgens Van Niekerk is Krog se verwerping van Eurosentrisme en die gepaardgaande opvatting oor die 'inherente superioriteit' van westerse moderniteit en rasionaliteit ' $n$ belangrike onderdeel van haar trilogie en wil sy dit voortdurend dekonstrueer. Anders as Van Niekerk, wat Krog bestempel as "n verbeeldingryke intellektueel' word in hierdie artikel getrag om aan te toon dat Krog se interpretasie van veral die Afrika-filosofie ernstige (intellektuele) leemtes vertoon én dat sy - anders as wat van 'n ware intellektueel verwag kan word - selde 'n kritiese afstand handhaaf. In die res van die artikel word

2.Corné Richter meld dit in 'n studievoorstel vir'n MA onder leiding van prof. Henning Pieterse (UV)

3. Country of my skull is eerste in Afrikaans geskryf en deur haar seun, Andries Samuel en Ivan Vladislavic vertaal. Ook A change of tongue is eers in Afrikaans geskryf, maar verskyn twee jaar later as die Engelse weergawe. 
dieper hierop ingegaan. Konsepte soos 'wit' en 'swart' is derhalwe, aldus Van Niekerk (WIT 2016:21), 'konstrukte' sonder enige vastigheid. Ras mag n kulturele konstruk wees; biologies gesproke bestaan daar onomstootlike bewyse dat sekere rasse geneties meer vatbaar vir sekere siektetoestande is, óf geneties beter vir bepaalde medikasie geskik is (kyk Brewster \& Seedat 2013; Brewster, Van Montfrans \& Kleijnen 2004; Burroughs, Maxey \& Levy 2002).

Van Niekerk bestempel Krog se trilogie as 'n voorbeeld van antirassisme. Hier is skynbaar'n verwarring: die aanvaarding van verskillende rasse is nie gelyk aan rassisme wat veronderstel dat rasse hiërargies geplaas word nie. Verder is dit so dat Krog ook skuldig is aan rassehiërargisering (swart is veel beter as wit; Van Niekerk se verbete pogings om dit af te maak as 'gebare' ten spyt) (WIT 2016:82).

Van Niekerk beweer dat Krog 'heelwat bestaande studies oor Moshoeshoe en die sendelinge Eugène Casalis en Thomas Arbouset geraadpleeg het ten einde haar eie verkorte weergawe van die geskiedenis van Moshoeshoe te verskaf'. Krog se bewondering vir hom blyk ook uit verwysing na 'Moshoeshoe' as 'a remarkable king' (WIT 2016:35). Krog stel by implikasie die sendelinge se poging om Moshoeshoe as't ware te beheer in hulle beperkte blik op morele kwessies (WIT:53) gelyk aan die Christelike appropriasie of toeëiening ('usurpation') van die waarheidskommissie - iets wat sy verwerp. Dat biskop Tutu, destydse aardsbiskop van die Anglikaanse kerk, dikwels as die argitek van die Waarheidsen-versoeningsverhore gesien word en die vertrekpunt aldus Christelik was, geniet min aandag by Krog, hoewel sy in Country of my skull waarderend oor hom skryf.

In WIT (2016:31) word gesê dat Krog van mening is dat 'interpretasies wat die radikale vergifnis wat die WVK-verhore moontlik gemaak het aan die invloed van die Christelike geloof toeskryf [...] tekortskiet'. So 'n stelling van Krog is aantoonbaar foutief, want biskop Tutu (die argitek van hierdie verhore) het tog deurgaans versoening ('vergifnis' in 'n Christelike sin) benadruk indien die volle waarheid deur beskuldigdes vertel is. In Van Niekerk se oorsig van 'postkoloniale momente' in die Suid-Afrikaanse geskiedenis, is dit opvallend dat sy min aandag aan die Afrikaner se onderdrukking deur die Engelse, en derhalwe kolonialisering deur hulle, bestee. Veral opvallend is dat daar hoegenaamd geen verwysing is na momente van Afrikaner-rebellie teen kolonialisasie soos die Groot Trek en die Eerste en Tweede Anglo-boereooloë nie. ${ }^{4}$ Van Niekerk wys daarop (WIT:37) dat Krog baie aandag aan 'die koloniale/postkoloniale gegewe' in Begging to be black bestee. Dan is dit juis opvallend dat daar slegs 'n skramse verwysing ('postkoloniale momente') deur Van Niekerk na die Afrikaner se eie stryd teen kolonialisme is.

Dalk is hierdie opvallende weglating ook toe te skryf aan die feit dat daar in Van Niekerk se bronnelys geen verwysing is na skrywers (soos F.A. van Jaarsveld, Fransjohan Pretorius, J.C. Steyn en Herman Giliomee) wat uitvoerig hieroor geskryf 4.Krog (1995:112-119) doen dit self wel en stel die gruwels van apartheid gelyk aan die ABO-vergrype. het en in baie gevalle (soos Giliomee) internasionale erkenning geniet nie. Krog se beskrywing van die Afrikaner se eeuelange stryd teen (koloniale) onderdrukking (en Van Niekerk se stilswyende onderskrywing daarvan) in die woorde: 'So Afrikaners who have so easily [sic] appropriated the land and the continent' (WIT 2016:37), getuig van weinig historiese besef en ' $n$ besonder eensydige perspektief op die verlede. Krog se eie interpretasie van die geskiedenis is soms ook enigsins bevooroordeeld deurdat sy wit mense as 'settlers' beskryf, maar die swart mense - wat hulle eweneens in bepaalde gedeeltes van Suider-Afrika gevestig het lank ná die oorspronklike bewoners (die Khoi en die San) - nie in hierdie terme tipeer nie.

In WIT (2016:41) meld Van Niekerk (sonder enige kritiese kommentaar) Mbeki se verwysing na die doringheg wat Jan van Riebeeck sou geplant het om die setlaars van die swart mense af te skei én na die wyse waarop Krog dit onderskryf. Dan Sleigh het reeds gewys op die foutiewe interpretasie hiervan; die heg is indertyd aangeplant om die beweging van vee te reguleer. Dit lyk asof Van Niekerk kritiekloos teenoor Krog se denke staan, omdat sy Krog se poging om die fenomeen Mugabe uit 'n Afrika-perspektief te probeer begryp (WIT:41), en Krog se stelling dat etiese optrede aan die hand van gemeenskapswaardes- en opvattings beoordeel kan word, kommentaarloos weergee. Petrus (in Disgrace) se verkragting van Lucy word binne die laasgenoemde redenering eintlik vergoeilik. Dit is kwalik vreemd, want volgens Renders (2012:88), aangehaal deur Van Niekerk (WIT:54), voel Krog dat selfs 'moord geregverdig is as die gemeenskap daarby baat'. Hierdie pogings van Krog om alles te regverdig of te verduidelik in terme van Afrika-denke blyk ook waar Tutu se beklemtoning van vergifnis (dié grondslag van Christelike denke) weer verduidelik (WIT:57) word as in 'Afrikanisering van versoening'. Krog se kontrastering van Mandela se verbintenis met sy gemeenskap en N.P. van Wyk Louw en sy klem op individualisme (die 'lonely individual'), verdien ook kritiese kommentaar van Van Niekerk. Enige letterkundige, selfs met slegs'n basiskennis van die Afrikaanse letterkunde, sal weet dat Louw se nasionalisme sentraal staan in sy denke. Trouens, die aristokratiese ideaal 'staan nie vreemd teenoor die volk nie [...]. Nog minder is dit individualisme wat van die gemeenskap afgekeer is. Dit is in wese die hoogste diens aan die gemeenskap' (Louw 1939a:35), en die 'groot eensames' waarna Krog verwys, is in Louw (1939a:182) se woorde 'vir ' $n$ volk noodsaaklik' (ons kursivering). Louw (1939b:37) sê elders dat die nasionalisme dieselfde eise aan 'ons jongeres' stel as 'n godsdiens en 'wat ons dwing om die hele persoonlikheid te stel in diens van 'n menslike gemeenskap [en jou eie kultuurgroep]'. 'n Sterker verbintenis met 'n gemeenskap is daar kwalik in die hele Afrikaanse letterkunde.

Nog 'n voorbeeld (wat Van Niekerk aanstip), is Krog se opmerkings oor die invloed van die Khoisan se wêreldbeeld op 'die sprekers van Bantoetale' (WIT 2016:65). Op bl. 67 noem Van Niekerk bloot terloops dat Krog se begrip van die 'Afrika-wêreldbeeld' eintlik op die Christelike geloof berus. 
In wese is dit verdoemende kritiek. Van Niekerk is wel uiters krities ten opsigte van Krog (WIT:71-73) en ten aansien van haar linguistiese analises. Vergelyk in hierdie verband Van Niekerk se opmerking: 'Die ongeldigheid van Krog se analise van die woord lekgoa laat egter deurskemer dat sy met bepaalde vooropgestelde idees na die woord lekgoa toe gekom het en uiteindelik té kreatief geraak het in haar interpretasies'. Hoe objektief 'n mens ook al probeer wees, Krog se denke grens soms aan 'n ideologies gedrewe, emosionele en selfs 'propagandisties' nie-intellektuele styl (kyk ook voetnoot 12; WIT:63).

\section{Krog en die Afrikafilosofie}

Van Niekerk (WIT 2016:73) wys daarop dat Krog 'n sterk belangstelling vir Afrikafilosofie het en tydens haar verblyf in Berlyn 'elke aand twee uur lank Afrikafilosofie lees'. Van Niekerk is besonder versigtig om Krog blatant van plagiaat te beskuldig en stel dit só: 'Krog se formulering van interconnectedness-towards-wholeness [het] moontlik veel te danke $[\ldots]$ aan Richard Bell [...]'. Ook die skrywers en werke wat sy aanhaal in haar artikels in Begging to be black 'is dikwels identies aan die inskrywings in Bell se bibliografie' (WIT:74). Die kwessie van plagiaat daar gelaat; Van Niekerk wys daarop dat Bell probeer om veral wit studente besorg te maak oor die onregte 'wat teenoor Afrikane gepleeg is' en hy wyt onverskilligheid aan onbegrip van Afrika en sy filosofie, veral die kommunale aspek daarvan. Geregtigheid staan nie voorop nie, maar eerder deernis en gulhartigheid. By Bell én Krog is daar 'n oorvleueling 'tussen die baie spesifieke gevallestudie van apartheid en die waarheidskommissie [sic] in Suid-Afrika, en die meer algemene onderwerp van Afrikakommunalisme, insluitende $u$ buntu' (WIT:75).

Die titel van Van Niekerk se werk tipeer volgens haar'n sentrale lyn in die drie werke van Krog wat sy in haar ontleding betrek, met name Country of my skull (1998), A change of tongue (2003) en Begging to be black (2010). Die 'baie worde' waarvan hier sprake is, dui nie op 'woorde' nie, maar op die onderliggende teenstelling tussen syn en wording. By herhaling en in verskillende gedeeltes van haar werk figureer die teenstelling tussen syn en wording. Syn word ook aan identiteit verbind, terwyl wording met transformasie in verband gebring word.

Van Niekerk verduidelik dat haar benadering interdissiplinêr is en dan vermeld sy dat dit dissiplines soos kultuurstudie, geskiedenis, politieke wetenskap en sielkunde omvat (WIT 2016:14). Hoewel die dissipline, Filosofie, hier weggelaat word, wys sy later tereg daarop dat Krog 'in haar trilogie in wese gemoeid is met fundamentele filosofiese vraagstukke' (WIT:23).

Nadere ondersoek toon egter dat daar nog verskeie ander filosofiese probleme is wat in Van Niekerk se geskrif na vore kom. Hoewel hierdie besinning die geskrif van Van Niekerk as toegangspoort gebruik, sal dieselfde wysgerige probleme figureer indien uitsluitlik van Krog se geskrifte gebruik gemaak sou word. In wat hieronder volg, word nader op filosofiese gesigspunte ingegaan, wat nie die outeurs se vindsel of die 'alleen-besit' van enige denktradisie is nie - dit deurkruis immers die filosofiegeskiedenis en die verskeidenheid vakwetenskappe wat vandag nog bestaan. Afrika-filosofie worstel op 'n eie wyse met dieselfde probleme.

\section{Fundamentele filosofiese vraagstukke}

Dinge wat pertinent in die onderhawige boek vermeld word, is die probleem van essensialisme, die probleemverhouding tussen universeel en individueel, tussen konstansie en dinamiek (duursaamheid en verandering), die probleem rakende die aard van die geheel-dele relasie, die vraag na identiteit-in-wording, die vraag na nasie, volk en staat, die verhouding tussen individu, gemeenskap en kommunaliteit, die vraag na die vermeende sosiale konstruksie van die menslike samelewing, swartheid en witheid, en 'n postkoloniale hunkering na 'becoming otherwise'.$^{5}$

Die verband tussen al hierdie probleme is dat hulle in Van Niekerk se boek én in Krog se publikasies (waarna Van Niekerk deurgaans verwys) voorkom. In wese gaan dit dus om bepaalde wysgerige probleme.

\section{Historiese wortels van wysgerige probleme}

Na aanleiding van Van Niekerk se opmerking dat die probleme waarmee sy en Krog worstel filosofies van aard is, word vanaf hierdie paragraaf tot en met die paragraaf, 'Sosiale omgangsvorme in 'n gedifferensieerde samelewing', hierop gefokus. Let egter daarop dat deurgaans van feitlike en immanente kritiek gebruik gemaak word. Die wysgerige probleme wat aan die orde gestel word, is universele probleme wat in alle filosofiese nadenke voorkom. Dit sal blyk dat bepaalde westerse antwoorde ook 'n invloed op Krog se denke gehad het - hoeseer sy graag vanuit 'n kommunale Afrikakonteks wil dink. Geen 'denksisteem' word tot absolute maatstaf verhef nie. Dit gaan immers om die erkenning van die ontiese stand van sake wat wysgerige probleme genereer wat nie die produk van enige 'denksisteem' is nie, maar waarvan alle 'denksisteme' op 'n eie wyse rekenskap moet gee. In die afdeling, 'Van eenheid en veelheid tot eenheid en verskeidenheid', staan byvoorbeeld: 'Aristoteles gee van dieselfde stand van sake op sy eie wyse rekenskap'. Immanente kritiek vloei daaruit voort dat 'n persoon haar- of homself in die gespreksgenoot se posisie plaas en dan die onhoudbaarheid daarvan aantoon. Daar word byvoorbeeld gestel: 'Krog weerspreek haar hier want vanuit haar voorkeur vir wording bejeën sy dit wat universeel en konstant is negatief'.

Van Niekerk meen dat 'Mandela aan Krog 'n les gee' oor 'wat ware menslikheid is'. Dit is ' $\mathrm{n}$ 'les in die superioriteit van kollektivisme teenoor westerse individualisme' (WIT:60). Word hiermee nie juis'n bepaalde denksisteem as absolute maatstaf verkies nie?

Van Niekerk besit self ' $n$ skerp kritiese instelling teenoor die individualistiese menseregte-opvattinge van die Weste. ${ }^{6}$

5.'n Geskrif waarin 'n verskeidenheid outeurs fokus op "other-wise' is onder die redakteurskap van Olthuis uitgegee (Olthuis 1997).

6. Krog verklaar dat 'sy nie "slegs" in 'n samelewing wil woon wat menseregte beskerm nie (BB 248)' (WIT 2016:114). 
Individualisme dui egter op 'n (teoretiese) skeeftrekking wat dan tegemoet getree word met 'n beklemtoning van gemeenskap en kommunaliteit wat ook as kollektivisties getipeer kan word. Hoewel die kollektivisme as teenpool van die individualisme gesien kan word, toon Van Niekerk se gebruik van hierdie term geen besef dat die kollektivisme bloot 'n wisselterm vir universalisme is nie en dat beide hierdie ismes, kollektivisme en universalisme, die ganse werklikheid in die keurslyf van die geheel-dele relasie wil inwring. In Strauss (2017b) word in meer besonderhede op die aard van hierdie relasie ingegaan.

Sonder om dit uit te spel, het ons hier van die transendentaalempiriese metode (TEM) gebruik gemaak. Die TEM stel allereers ondersoek in na dit wat aan ons ervaring ten grondslag lê en moontlik maak (transendentaal) en let vervolgens op die variabele (empiriese) gegewens wat ons op hierdie basis kan ervaar.

Die geheel-dele relasie vind tewens sy oorspronklike tuiste in die ruimte-aspek, waar 'n homogene geheel sonder einde verder verdeel kan word. Waar matematiese ruimte sowel oneindig verdeelbaar as kontinu is, is fisiese ruimte nie kontinu nie (dit is gebonde aan die kwantumstruktuur van energie) en derhalwe ook nie sonder einde verdeelbaar nie. Die tradisionele siening wat alles in die menslike samelewing deel van die staat wil maak (soos die Griekse polis of stadstaat), of (later gedurende die middeleeue) weer sien as deel van die kerk as omvattende geheel, kan nie reg aan die unieke eie aard van die verskillende samelewingsvorme laat geskied nie.

Dat bedrywe, gesinne en kerke nie deel van die staat is nie, is eers aan die begin van die sewentiende eeu deur Johannes Althusius ingesien. Egte dele van die staat is provinsies en munisipaliteite (Althusius 1603:16). Volgens hom is daar 'proper laws (leges propriae)', wat spesifieke assosiasies struktureer ooreenkomstig die natuur daarvan (Althusius 1614 - soos vertaal deur Carney in die inleiding van die 1965-uitgawe). Kring-soewereine samelewingsvorme is nie deel van een of ander samelewingsgeheel nie.

So stel Van Niekerk Descartes se individualistiese 'I think' teenoor (die kollektivistiese) 'because I am with you' (WIT 2016:59). Op die volgende bladsy merk sy op dat Mandela aan Krog 'n les gee oor 'wat ware menslikheid is' - 'n 'les in die superioriteit van kollektivisme teenoor westerse individualisme' (WIT:60).

\section{Watter wysgerige probleme lê aan die individualisme en universalisme ten grondslag?}

Nóg Van Niekerk, nóg Krog verduidelik egter presies met watter 'fundamentele filosofiese vraagstukke' hulle besig is. Die kernvraag is immers: Watter wysgerige probleem gee aanleiding tot dit wat hulle as 'n individualistiese benadering bestempel? Asook, watter wysgerige probleem het tot 'n kollektivistiese of universalistiese antwoord daarop aanleiding gegee?
Hiermee word ondersoek ingestel na die probleemvrae [werklikheidsgegewens] waarop die skeeftrekking wat in die individualisme en universalisme aangetref word, berus. Die vraag is dan of ' $n$ 'werklikheidsgetroue' antwoord ook daarop gegee kan word, waaruit die verduideliking dan voortvloei.

In beide gevalle kan bykomend gevra word: Is dit moontlik om ook 'n positiewe (onproblematiese) antwoord op die onderliggende probleme van hierdie ismes te gee - dit wil sê 'n 'isme-vrye' of 'werklikheidsgetroue' antwoord? In die geval van die individualisme is die agterliggende wysgerige grondprobleem in die vraag na die ene en die vele gegee - 'n onmiskenbare appèl op die getalsaspek van die werklikheid.

\section{Van eenheid en veelheid tot eenheid en verskeidenheid}

Enersyds lê hierdie aspek aan ons ervaring van 'n onderskeie hoeveelheid individuele dinge en gebeurtenisse ten grondslag. Verskillende getalsbegrippe kan hier na vore tree, soos die begrip van natuurlike getalle, heelgetalle, breuke, reële en imaginêre getalle. Andersyds kan ons getalsbesef ook ingespan word om na gegewens te verwys wat die grense van die kwantitatiewe aspek te bowe gaan, oorskry of transendeer. In hierdie geval gaan dit om begripstransenderende (idee-)gebruike van getalsterme. Dink byvoorbeeld aan die besef van die onderskeidenheid van enigiets (its being distinct), of aan die uniekheid van enige gegewe. Laasgenoemde hou ook verband met die idee (in 'n begripstransenderende sin bedoel) van eenheid en verskeidenheid (sien Russell 1956:346).

Monistiese ismes, soos fisikalisme, vitalisme, psigologisme, moralisme, en historisme bevat almal (negatiewe) antwoorde op die vraag na eenheid en verskeidenheid. Vanuit die perspektief van begripstransenderende (idee-)kennis gaan dit hier oor die erkenning van die samehang van wat uniek is. Die volgende twee stellings is daarom werklikheidsgetrou: alles is uniek; en alles hang met alles saam. Elke (teoretiese) werklikheidsvisie moet gevolglik van die samehang van wat uniek en onherleibaar is (the coherence of irreducibles), rekenskap gee.

Hou hierby in gedagte dat die werklikheidsaspekte nie alleen bestaanswyses (modes of being) is waarbinne konkrete dinge funksioneer nie, want dit is tegelyk ook verklaringswyses.

\section{Die tweërlei betekenis van universalisme}

Let bykomend daarop dat die term 'universalisme' op tweërlei wyse gebruik kan word: eerstens om 'n oorbeklemtoning van universaliteit aan te dui, of tweedens om 'n oorwaardering van die ruimtelike geheel-dele-relasie te belig. In eersgenoemde geval is die onderliggende wysgerige probleem gegee in die vraag na die verhouding tussen dit wat universeel is en dit wat individueel is - 'n wysgerige probleem wat slegs implisiet en indirek in die geskrif van Van Niekerk aan die orde gestel word. ${ }^{7}$ Die tweede betekenis

7.Vergelyk egter die vraag wat Van Niekerk vra: 'Is daar universeel geldige opvattings oor wat reg en verkeerd is, of kan dit verskillende betekenise in verskillende kulture hê?' (WIT 2016:53) 
van die term universalisme handel oor die oorspronklike ruimtelike aard van die geheel-dele-relasie. ${ }^{8}$ 'n Groep Franse wiskundiges beskou ruimtelike kontinuïteit selfs as funderend vir diskreetheid. Longo (2001) verwys na Thom:

... who believes that continuity precedes discreteness: For him, as for many mathematicians of the continuum, 'the Continuum precedes ontologically the discrete', for the latter is merely an 'accident coming out of the continuum background', 'a broken line'. (bl. 6)

\section{Universeel en individueel: Rasionalisme en irrasionalisme}

Die geskiedenis van die filosofie (asook die geskiedenis van al die natuur- en geesteswetenskappe) belig eensydige waarderings van die universele en die individuele wat tot uitdrukking kom in rasionalistiese en irrasionalistiese denkstrominge. Aangesien begripsvorming op universaliteit berus, dit wil sê op universele eienskappe of kenmerke wat in in logiese begrip verenig word, kan in oorbeklemtoning van begripskennis as rasionalisties getipeer word. Daarteenoor berus die irrasionalisme op 'n oorwaardering van begripstransenderende (of: idee-)kennis. Wat individueel is, oorstyg die greep van begripskennis, want begrippe is blind vir die individuele - soos reeds treffend deur die Middeleeuse Skolastiek verstaan is: 'individuum ineffabile' ('die individuele is onuitspreeklik') en: 'oor die singuliere is geen wetenskap moontlik nie' ('de singularibus non est scientia') (kyk Janich 2009:110). Hierdie teenstelling hou ook verband met die aard van die realisme en die nominalisme.

\section{Die verskraling wat in monistiese -ismes opgesluit lê}

Die bespreking van die 'verskraling wat in monistiese ismes opgesluit lê' volg dieselfde ontledinspatroon. Dit ondersoek dit wat in die werklikheid gegee is voor enige menslike konstrukte ontwikkel is.

Die Pythagoreërs was oortuig alles is getal (kyk by Fowler 1999:8-10, 23, 52-53, 303-305 en Riedweg 2005:84-85, 124-128). Die atomisme en selfs die kontemporêre individualisme probeer nog steeds om die ganse werklikheid getalsmatig uit laaste diskrete eenhede te verklaar. Gedurende die twintigste eeu betree beide die metodologiese individualisme en die metodologiese holisme die toneel.

\section{Die synsmetafisika van Parmenides}

Vervolgens (in die volgende twee onderafdelings) word daarop gewys hoe Parmenides 'n synsmetafisika ontwikkel het wat op die probleem van syn en wording afstuur wat sentraal in die werk van Van Niekerk en Krog staan. Wanneer langs in transendentaal-empiriese weg (TEM) aangetoon word dat die kinematiese en fisiese aspekte van die werklikheid uniek is en onverbreeklik saamhang, word na stande van sake verwys sonder om 'n eie standpunt te oorskat.

8.In Strauss (2017c) word in meer besonderhede op die geheel-dele-relasie as sodanig ingegaan.
Histories gesien het die skool van Parmenides hierdie getalsperspektief laat vaar ten gunste van 'n (statiese) ruimteoriëntasie. Dit het geskied as gevolg van die ontdekking van irrasionale getalle (deur die ontdekking van inkommensurabele verhoudinge). In sy derde B Fragment stel Parmenides syn en denke gelyk: 'Want dieselfde is denke en syn' (Diels-Kranz 1959-1960:B Fr. 3). Die syn is en slégs die synde is (B Fr. 6). Dit sou egter veral B Fr. 8:3-6 wees wat 'n blywende invloed op die westerse denkgemeenskap uitoefen. Sommige van die terme wat ons in hierdie snit aantref, word begripsmatig gebruik en andere in $n$ begripstransenderende sin. Aan die toutologiese bevestiging dat dit wat is is, verbind Parmenides vele kenmerke: 'aangesien ongebore is dit ook onverganklik, [...] en dit was nie en sal nie wees nie, aangesien dit in die hede [nou] tesame voorhande is as geheel, een, samehangend (kontinu)'.

Die besef van 'n geheel en van samehang, belig sleutelelemente van ons ruimtebegrip. Soos reeds vroeër opgemerk is, is iets wat kontinu is, eindeloos verdeelbaar - en elke deel is aan aangrensende dele (gapingloos) gekonnekteer. Wanneer al die dele (gelyktydig) aanwesig is, vorm hierdie gekonnekteerde menigvuldigheid van dele'n samehangende geheel. Parmenides gebruik die relasie tusssen 'n geheel en die dele daarvan dus as sleutel om die ganse heelal te verstaan.

\section{Die Griekse polis (stadstaat) as perfekte samelewingsgeheel}

In die Griekse siening van die polis (stadstaat) word dit verhef tot die omvattende geheel van menswees wat alle ander samelewingsgeledinge as egte dele omvat. Aristoteles giet hierdie universalistiese siening in die vorm van die gedagte dat die geheel aan die dele voorafgaan: 'Daarom gaan die staat, kragtens sy natuur, vooraf aan die familie en die individu, aangesien die geheel aan die deel moet voorafgaan. ${ }^{\prime 9}$

Krog (Krog 2008) konkludeer in 'n artikel van haar oor die Waarheid-en-versoeningskommissie dat die morele kompas van hierdie proses in ' $n$ tipe geheelheid te vinde is wat in 'n radikaal nuwe inheemse siening van wording en syn ingebed is:

This throws a sharp light on a different way of becoming and being. Sustained scholarship into the formation, sustainability, integrity and moral compass of interconnectedness-towards-wholeness could lead to a more informed discourse around events happening on the African continent. (bl. 365)

Vanuit 'n vermeende inheemse Afrika-perspektief word syn en wording op die proseseindpunt van geheel-wees gerig. Vanaf die synsgeheel van Parmenides (tesame in die nou), ${ }^{10}$ via die polis van Aristoteles as samelewingsgeheel, ontmoet ons by Hegel, gedagtig aan Parmenides se gelykstelling van denke en syn, 'n sonderlinge geheel, want in sy vroeë geskrif, 'Phänomenologie des Geistes', stel hy waarheid en geheel gelyk: 'Das Wahre ist das Ganze'. Die kwalifikasie wat Hegel hieraan

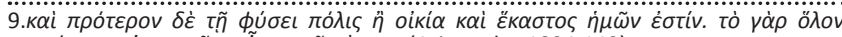

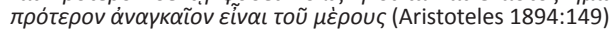

10.Plotinus dra by tot die vestiging van die denktradisie waarin die tydlose hede (nou) as ewigheid waardeer word. Vgl. bloot Kierkegaard se 'nunc aeternum' en Wittgenstein se opmerking dat as ewigheid tydloosheid is, hy die ewige lewe besit wat in die hede leef (Wittgenstein 1961:146-6.4311). 
verbind, is soortgelyk aan die klem wat Krog lê, want Hegel stel: 'Die geheel is egter slegs dit [die ware] deur die ontwikkeling van sy voleindigende wese' ${ }^{11}$

Die frase dat lig gewerp word op 'a different way of becoming and being' veronderstel dat daar in die intellektuele geskiedenis van die Weste ' $\mathrm{n}$ standaard manier is om oor die verhouding tussen syn en wording te dink. Die titelkeuse van Van Niekerk se werk bevat immers die naas-mekaar-stel van identiteit en transformasie watin dieprobleem vankonstansie(duursaamheid) en verandering (dinamiek) ingebed is. Uit haar behandeling van Krog se trilogie blyk dit dat sy daarop ingestel is om 'n 'identiteit van konstante wording [te] omhels (sic!)':

Die konsep van ubuntu oftewel interkonneksie suggereer enersyds vir Krog 'n radikaal anderse manier om in en van die wêreld te wees in die wyse waarop dit resoneer met Krog se begeerte om'n egoïstiese sin van self te ondergrawe en'n identiteit van konstante wording te omhels. (WIT 2016:117)

Die kernvraag hier is die volgende: Is daar nog ruimte vir identiteit indien dit deur wording (verandering) gekenmerk word? Loop wording nie onvermydelik uit op iets wat 'nieident' is nie?

In een van haar Berlyn-gesprekke bring Krog die 'interconnectedness' van die Afrika-'world view or philosophy' ter sprake. Wat van die San (eerste mens) afkomstig is, is die 'broad philosophy of an interconnectedness towards something more spiritual, ${ }^{12}$ more whole, more towards the potential power of everything' (WIT 2016:30).

\section{(On-)gebroke geheel?}

Die klem wat Krog deurgaans op 'interconnectedness-towardswholeness' lê, leun sterk aan op die rasionalistiese erfenis wat by die vermelde synsmetafisika van Parmenides begin en via Hegel na eietydse universalistiese opvattinge deurwerk. Die postitiewe spreke van 'n GEHEEL besit gewyde ondertone, maar anders as by die skool van Parmenides waar eenheid voorop staan, sien ons dat Krog voorkeur gee aan 'veelvoudigheid' ('verskeidenheid' of 'heterogenïteit') (WIT 2016:7).

Dit is duidelik dat Krog se denke op hierdie punt 'n dialektiese tweespalt vertoon. Aan die een kant dui inter-konneksie op die weg na die geheel, bemiddel deur die element van 'wording' wat in die woord 'towards' opgesluit lê: 'interconnectednesstowards-wholeness'. Om 'n geheel te wees, moet dit as 'n totaliteit gelyktydig al sy dele omvat. Drie sye in suksessie lewer nog nie 'n driehoek as tweedimensionele ruimte-figuur nie.

Die kenmerke van hierdie gawe geheel word egter gerelativeer deurdat Krog andersyds identiteit en wording ineentrek. Van Niekerk kom daarom tereg tot die gevolgtrekking dat Krog se

11.Das Ganze aber ist nur das durch seine Entwicklung sich vollendende Wesen (Hegel 1807:21).

12.Vergelyk die subtitel van Olthuis se 1997-werk 'Knowing other-wise': Philosophy at the threshold of spirituality. vraag na identiteit in die trilogie uiteindelik tot rus kom by 'identiteit-as-wordingsproses' (WIT 2016:13). Vergelyk Deleuze en Guattari se oortuiging dat 'menslike subjektiwiteit 'n radikale veelvoudigheid' is (vermeld in WIT:27). Krog verbind die prioriteit wat sy aan wording gee met veelvoudigheid en verskil (bo eenvormigheid): 'die mens moet leer om eerder dit te kies wat positief en veelvoudig is; hy moet verskil bo eenvormigheid kies, vloeiinge bo eenhede, mobiele rangskikking bo sisteme' (beklemtoning deur outeurs Van Niekerk WIT:26). ${ }^{13}$

Dit bring ons terug na die Griekse filosofie waar die verhouding tussen syn en wording (identiteit en transformasie) van meet af aan prominent was.

\section{Die Griekse wortels van syn en wording}

Wat is die historiese agtergrond van die wysgerige probleem rakende syn en wording?

Die vroegste Griekse filosofie worstel reeds met die vraag hoe ons kan beweer dat iets is, terwyl alles in ons ervaringswêreld skynbaar voortdurend verander. Krog probeer om uit hierdie dilemma te kom deur vanuit die voorrang wat sy aan wording gee, te stel dat verandering die enigste konstante is.

Van Niekerk verwys na Anker wat beweer dat Krog se trilogie oor verandering wat gedemonstreer word, handel. Om te 'skryf is om anders te word' - en 'Om te filosofeer is om anders te dink'. ${ }^{14}$ ' $\mathrm{n}$ Voortdurende proses van verandering waar transformasie - van die self in die teks, van die teks as sodanig, van die gedagtes - die enigste konstante is wat verlang word (WIT 2016:27).

Binne die Griekse wysgerige denke sou die substansiebegrip spoedig, veral deur Plato en Aristoteles, ingespan word om hierdie probleem te bowe te kom.

Op die kruispunt van die oorgang van die AristoteliesThomistiese erfenis na die era van die moderne wysgerige denke, omskryf Descartes die begrip 'substansie' nog in klassieke terme: 'By substance we can conceive nothing else than a thing which exists in such a way as to stand in need of nothing beyond itself' (Descartes 1965:184).

Die substansiebegrip in Aristoteles se denke dien as die vertrekpunt vir die vraag na die verhouding tussen universaliteit en dit wat individueel is, asook vir die ewe invloedryke onderskeiding tussen wese en verskyning. Die wese van iets sou

13. Deur vloeing teenoor sisteem te stel word die problematiese aard van hierdie siening gedemonstreer, want die vloeiende ewewig wat, termodinamies gesien, in lewende dinge aanwesig is, berus op Von Bertalanffy se veralgemening van die tweede hoofwet tot oop sisteme (kyk Schrödinger 1955). Op die vlak van die lewende sel gaan dit oor metaboliese prosesse (opbou- en afbreekprosesse, of lewende sel gaan dit oor metaboliese prosesse (opbou- en afbreekprosesse, of anabolisme en katabolisme). Von Bertalanffy tipeer hierdie situasie as ' $n$ vloeiende ewewig ('n Fliessgleichgewicht, wat in Engels as 'steady state' aangedui word). Schrödinger praat van 'negatiewe entropie', wat beteken dat lewende dinge die verval tot ' $n$ toestand van fisiese ekwilibrium vermy deur negatiewe entropie as
voedsel te gebruik (WEB uitgawe, bl. 46-47).

14.Eenderse denke en anderse denke bly weliswaar nog steeds denke - dit verander nie in nie-denke nie. 
op duursaamheid of selfs onveranderlikheid dui, terwyl die eienskappe van die substansie veranderlikheid in die visier het. Ter Horst (2008) som die oes van die Griekse filosofie in hierdie opsig soos volg op:

De oplossing van Parmenides en in mindere mate van Democritus is om:

het worden te herleiden tot het zijn. De oplossing van Heraclitus is om het zijn te herleiden tot het worden. Plato's oplossing is om zowel het worden als het zijn te behouden door ze over verschillende domeinen te verdelen. Aristoteles' oplossing tenslotte poogt beide te behouden door ze op een heel bepaalde wijze met elkaar te verenigen. (bl. 68; sien ook Strang \& Mills 1974)

Gedurende die Griekse en Middeleeuse eras het konkrete dinge die middelpunt van die belangstelling gevorm. Die verganklikheid of veranderlikheid wat dinge in die sfeer van wording (genese) volgens Plato besit, wou hy kontrasteer met iets duursaams, iets wat bo die verganklike wording uitstyg. As alles immers voortdurend verander, sal enige kennis daarvan onmoontlik wees, want sodra iets begripsmatig in die greep gekry is, het dit reeds weer in iets anders verander.

\section{Verandering kan slegs op die basis van duursaamheid vasgestel word}

Dieselfde geld van verandering wat slegs op die basis van duursaamheid vasgestel kan word. Plato, Galilei en Einstein het almal op hierdie onties-gegewe stand van sake gestuit, maar tog uiteenlopend daarvan rekenskap gegee.

In sy dialoog, Phaedo, werk Plato hierdie siening in sy oorspronklike vorm uit. Hy onderskei alles wat onsigbaar en konstant is en slegs verstandelik bedink kan word van alles wat sigbaar en veranderlik is en bloot deur middel van die sintuie waargeneem kan word (Plato 1973; Phaedo 79d).

Plato is gekonfronteer met die leerstelling van Herakleitos, naamlik dat alles voortdurend verander (panta rei) (Herakleitos, sien Diels-Kranz, B Fr. 90). 'n Jonger tydgenoot van Plato, genaamd Kratylus, het Herakleitos se opvatting radikaal deurgetrek en selfs beweer dat omdat alles verander, niemand ooit iets kan ken nie. In Plato se gelyknamige dialoog, Kratylus, vind ons sy worsteling met hierdie probleem. As niks enige houvas bied nie, kan daar ook geen sprake van identiteit wees nie.

Om hierdie probleem te bowe te kom, het Plato gevolglik 'n bo-sinnelike ryk van statiese synsvorme gepostuleer waarin hul ewige essensie (wese) veranker is. Te midde van alle verandering sou hierdie ontiese vorms konstant bly. Hierdie spekulatiewe ryk van ewige, onveranderlike synsvorme beliggaam Plato se antwoord op die probleem van duursaamheid en verandering (konstansie en dinamiek of syn en wording).

Hoewel ons nie vandag nog Plato se ryk van ideë hoef te aanvaar nie, kan ons tog nie aan sy prinsipieel korrekte insig ontkom nie, naamlik dat verandering slegs op die basis van konstansie vasgestel kan word. Indien konstansie inderdaad 'n voorwaarde vir verandering is, is die volgende probleem hoe ons hierdie insig sistematies moet verantwoord.

Galilei het in 1638 'n gedagte-eksperiment geformuleer waarin hy aan 'n bewegende liggaam dink. Indien hierdie baan tot in die oneindige uitgestrek is, sal 'n liggaam wat eenmaal in beweging is se beweging tot in die oneindige voortgesit word - tensy 'n krag (soos wrywing) daarop inwerk. Galileo (1914) skryf:

Imagine any particle projected along a horizontal plane without friction; then we know, from what has been more fully explained in the preceding pages, that this particle will move along this same plane with a motion which is uniform and perpetual, provided the plane has no limits. (bl. 244)

Dit gaan dus daarom dat 'eenvormige' of 'eenparige' beweging suiwer kinematies verstaan moet word. Net soos wat getal en ruimte in eie reg teoretiese verklaringsprinsipes is, tree beweging hier as ' $n$ oorspronklike (en onherleibare) verklaringsbeginsel na vore. Die implikasie is dat fisici nie na die oorsaak van beweging kan vra nie, hulle kan slegs van die oorsaak van 'n verandering van beweging praat (vertraging of versnelling). Dit gaan hier om die uniekheid en funderende samehang tussen die kinematiese en fisiese aspekte van die werklikheid, wat Max Planck (1973:65) selfs daartoe bring om van 'n meganiese en 'n energetiese natuurbeskouing te praat. ${ }^{15}$ In 'n ander konteks onderskei Janich (1975:68-69) ook tussen foronomiese (kinematies genoem) en dinamiese uitsprake.

Hierdie insig in die uniekheid en wedersydse onherleibaarheid van die kinematiese en fisiese aspekte vorm ook die kruks van Einstein se (spesiale) relatiwiteitsteorie. Einstein postuleer immers 'n 'snelheid-bo-grens' - 'n eis waaraan die vakuumsnelheid van lig beantwoord: alle beweging is relatief tot hierdie konstante. Daarom is Einstein se teorie in die eerste plek ' $n$ teorie van konstansie en nie van relatiwiteit nie (kyk Strauss 2010).

Die probleem van syn en wording waarmee beide Van Niekerk en Krog worstel, kan nou in die lig van die voorafgaande opmerkings anders waardeer word:

- Dit is nie sinvol om hierdie twee momente in opposisie tot mekaar te plaas nie.

- Die eintlike probleem waaroor dit gaan, raak die relasie tusssen konstansie (syn) en dinamiek (duursaamheid verandering - wording).

- Duursaamheid appelleer op die kinematiese aspek van eenparige (konstante) beweging.

- Dinamiek (verandering) kom oorspronklik in die fisiese aspek van energiewerking voor - wanneer energie werk, tree daar veranderinge in (word gevolge veroorsaak kousaliteit). In ander aspekte word analogieë van fisiese kousaliteit gevind; vergelyk byvoorbeeld logiese kousaliteit (die grond en gevolgtrekking van'n argument); sosiale kousaliteit en juridiese kousaliteit.

15.Planck (1973:53) wys ook daarop dat die meganiese beskouing agterhaal is toe dit geblyk het dat alle fisiese verskynsels nie tot beweging herlei kan word nie. 
- Verandering kan egter slegs op die basis van duursaamheid vasgestel word.

- Wanneer konstansie of duursaamheid onderwaardeer word, bly identiteit in die slag.

- In die postmoderne denke word verandering beklemtoon ten koste van duursaamheid (kyk Strauss 2004).

- In Krog se denke word konstansie negatief waardeer en word die swaartepunt op wording (verandering) geplaas.

Hierdie agt punte belig die gebruik van die TEM (transendentaal-empiriese metode).

Tegelykertyd voer hierdie oorwegings ons gedagtegang terug na die titel van Van Niekerk se werk. Die strekking van die titelkeuse van Van Niekerk se werk word uiteindelik deur Krog ondergrawe, aangesien sy die 'syn' aan die 'wording' opoffer. Met verwysing na Stuart Hall, word beide syn en wording skynbaar 'gelykberegtig', byvoorbeeld wanneer kulturele identiteit as 'a matter of "becoming" as well as of "being" gesien word. Die opmerking wat nogtans onmiddellik hieraan toegevoeg word, stel dat kultuur inherent histories van aard is en daarom steeds aan konstante transformasie onderworpe is:

It belongs to the future as much as to the past. It is not something which already exists. [...] But, like everything which is historical, they undergo constant transformation. Far from being eternally fixed in some essentialised past, they are subject to the continuous 'play' of history, culture and power. [...] identities are the names we give to the different ways we are positioned by, and position ourselves within, the narratives of the past. (Stuart Hall 1990:222; WIT 2016:109)

Krog se spreke van 'identiteit-as-wordingsproses' beteken dat die titel van Van Niekerk se werk omvorm sou kon word van identiteit en transformasie tot by die transformasie van identiteit. Krog se beklemtoning van wording voer haar denke tot vlakby die inherente impasse van die historistiese oortuiging dat alles geskiedenis (historiese wording) is. Dit wat die basis is op grond waarvan ons historiese veranderinge kan vasstel, kan egter nie inherent histories van aard wees nie. Anders gestel: slegs dit wat nie geskiedenis is nie, kan 'n geskedenis hê. Die tragiese ironie van alle eensydige ismedenke skemer hier deur, want 'n isme-oriëntasie bereik steeds die teendeel van wat beoog word. As alles - juridiese standaarde, geloofsoortuigings, ekonomiese waardes, estetiese beginsels, en so meer - histories van aard is, is daar niks oor wat 'n geskiedenis kan hê nie ('n geskiedenis van 'n geskiedenis is 'n kontradiksie in terme). Danksy die ontiese universaliteit van die verskillende werklikheidsaspekte kan ons egter tereg gegewens soos geloofsgeskiedenis, regsgeskiedenis, kunsgeskiedenis (insluitende literêre geskiedenis) en eknomiese geskiedenis onderken juis omdat hierdie aspekte nie self inherent histories van aard is nie.

\section{Universeel en individueel in Aristoteles se substansiebegrip}

In hierdie paragraaf word die blik verruim om ook van die probleem van universeel en individueel rekenskap te gee (insluitende die aard van die realisme en nominalisme) - wat in samehang met die probleem van duursaamheid en verandering en aan die probleem van identiteit en transformasie ten grondslag lê.

Aristoteles se substansiebegrip betree die uiteensetting van Van Niekerk vanuit die hoek van die verhouding tussen wat universeel en wat individueel is. Wanneer hy aan die begin van sy werk Categoriae die idee van 'n primêre substansie invoer (die proten ousian), sien Aristoteles dit as totaal uniekindividueel. Ons het egter reeds opgemerk dat die klassieke opvatting is dat begripsvorming vir die individuele blind is. Gevolglik moes Aristoteles 'n sekondêre substansie invoer - die universele wesensvorm of selfstandigheidsvorm van die substansies - om die bestaan van begripsvorming en teoretiese denke te red. Hy (Aristoteles 2001) skryf:

All substance appears to signify that which is individual. (10) In the case of primary substance this is indisputably true, for the thing is a unit. In the case of secondary substances, when we speak, for instance, of 'man' or 'animal', our form of speech gives the impression that we are here also indicating that which is individual, but the impression is not strictly true; (15) for a secondary substance is not an individual, but a class with a certain qualification; for it is not one and single as a primary substance is; the words 'man', 'animal', are predicable of more than one subject. (bl. 12; Kategorieë 5:10-18).

Volgens Aristoteles is 'n substansie uit vorm en materie saamgestel, wat die saamdink van twee teengestelde (eintlik: wederkerig uitsluitende) oorsprongbeginsels beliggaam (die materie is vormloos en die vorm materieloos - kyk na die omvangryke werk van Happ 1971). Teenoor die primêre substansie wat individueel is, beklemtoon Aristoteles dat die sekondêre substansie die universele wesensvorm van die dinge is. (Hierdie universele wesensvorm word ook as die 'formula' in Engelse vertalings aangedui).

Plato se postulering van die eie wese (auto to eidos) van die bosinnelike ewige synsvorme bevat ' $n$ implisiete insig in die orde vir dinge. Dit wil sê, Plato se spekulatiewe ideëleer stuit teen die wet vir (kondisies vir) dinge. Deurdat Aristoteles egter hierdie transendente orde vir aftrek en immanent in die dinge plaas, blyk dit dat hy van die aard van ordelikheid of wetmatigheid wil rekenskap gee. Wetmatigheid dui op dinge enigiets - wat die maat van die wet besit. Met ander woorde, die maat van die wet (wetmatigheid) is 'n eienskap van dinge wat aan die wet onderworpe is en kan gevolglik nie met die wet (as orde vir) vereenselwig word nie.

Die agtervoegsel '-heid' belig hierdie stand van sake uit 'n ander hoek. In haar verduideliking van wat Krog onder ubuntu verstaan, vermeld Van Niekerk byvoorbeeld gemeenskaplikheid (WIT 2016:64) en menslikheid (WIT:60). Wanneer menslike samesyn beantwoord aan die eise (orde) vir gemeenskap-wees, ontmoet ons gemeenskaplikheid. Insgelyks, wanneer aan die eise vir mens-wees beantwoord word, ontmoet ons menslikheid.

\section{Wet en wetmatigheid}

Met die oog op die onverbreeklike korrelasie tussen individueel en universeel, kan gestel word dat elke individuele 
gemeenskap ' $n$ gemeenskap is, net soos wat elke individuele mens ' $n$ mens is. Met ander woorde, in die gemeenskapwees van 'n gemeenskap toon hierdie gemeenskap dat dit 'n gemeenskap is.

Elke entiteit besit dus sowel ' $n$ individuele as 'n universele kant - onderskeidelik met behulp van die onbepaalde en bepaalde lidwoorde aangedui: '(hier)die' en "n': Hierdie mens is ' $n$ mens en hierdie atoom is ' $n$ atoom. In sy atoomwees toon hierdie individuele atoom op 'n universele wyse dat dit aan die (universele) orde vir (wet vir) atoomwees beantwoord.

Wanneer Van Niekerk aandag skenk aan Krog se worsteling met 'witheid' en 'swartheid', is die onderskeidings wat ons pas verduidelik het, relevant. Dit hang egter saam met die aanklag van 'essensialisering' wat Van Niekerk aan die adres van Krog rig (WIT 2016:81).

Die wysgerige probleem is duidelik: Hoe moet ons die verhouding tussen individueel en universeel verantwoord? Die onderskeiding tussen individueel en universeel moet aan die onderskeiding tussen orde vir en ordelikheid van individuele dinge gekoppel word.

Aristoteles gee van dieselfde stand van sake op sy eie wyse rekenskap. Wording (genese) en tot niet gaan, betref volgens hom nie die formula in die universaliteit (generality) daarvan nie: 'the being of house is not generated, but only the being of this house' (Aristoteles 2001:807).

\section{Realisme en nominalisme}

Die realistiese metafisika van die Middeleeue aanvaar drie universalia: (1) Universalia ante rem in God se Gees (Plato se ideë - via die neo-Platonisme gekontinueer); (2) universalia in rei (Aristoteles se wesensvorme); en (3) universalia post rem (begrippe in die menslike gees). Laat in die Middeleeue is hierdie realistiese erfenis egter deur die nominalisme (Ockham en andere) bevraagteken deurdat universaliteit buite die menslike gees ontken is.

Dit beteken enersyds dat die wet vir (orde vir) dinge ontken word, en andersyds dat ook die ordelikheid (wetmatigheid) van dinge misken is.

Die realistiese waarheidskriterium, die ooreenstemming van denke en syn, is deur die nominalime getransformeer tot die versoenbaarheid van begrippe in die menslike gees (in mente humana). ${ }^{16}$

Die gebrek aan orde-bepaaldheid impliseer dat die werklikheid buite die menslike gees struktuurloos en chaoties is - 'n leemte wat spoedig deur die motief van logiese

16.Let daarop dat die nominalisme tegelyk rasionalisties en irrasionalisties is rasionalisties ten opsigte van die universele bgrippe in die menslike gees en irrasionalisties met betrekking tot die puur individuele aard van die dinge buite di menslike gees. Na die opkoms van die historisme gedurende die 19de eeu is die universaliteit van hierdie motief gerelativeer sonder dat die onderliggende ide prysgegee is. Sedertdien verneem ons ook van die sosiale konstruksie van die werklikheid. Dink aan die werke van Schutz (1974) en na hom die geskrif van Luckmann en Berger (1969). skepping gevul sou word. Hobbes formuleer 'n gedagteeksperiment waarin die werklikheid eers tot 'n puinhoop afgebreek word alvorens dit met behulp van die begrip van bewegende liggaam teoreties gerekonstrueer word. In die denke van Immanuel Kant bereik hierdie nuwe motief sy eerste hoogtepunt, want hy verhef die menslike verstand tot die apriories formele wetgewer van die natuur: 'Die verstand skep sy wette (a priori) nie uit die natuur nie, maar skryf dit aan die natuur voor' (Kant 1968:II:320; § 36). In die eerste uitgawe van sy Kritiek van die suiwere rede, stel Kant dat die orde [wette] en die wetmatighede van die natuur nie deur die mens uitgelig sou kon word as dit nie deur die mens self in die natuur gelê is nie. ${ }^{17}$ In Kant se denke vind ons hier die rasionalistiese hoogtepunt vir die moderne nominalisme wat by Van Niekerk gewysigd naleef in haar opvatting van 'konstrukte'.

\section{Essensialisme}

Die wyse waarop Van Niekerk na essensialisme verwys, hang ten nouste saam met haar nominalistiese siening van universaliteit en haar (en Krog se) postmoderne negatiewe verstaan van duursaamheid (as 'onveranderlikheid'). Teenoor essensialisme stel sy konstruktivisme. Sy omskryf essensialisme soos volg:

Essensialisme of essensialisering, die aanname dat ons dinge kan waarneem soos wat hulle in essensie is en dat lede van 'n bepaalde groepering almal dieselfde essensie besit, is die teenoorgestelde van konstruktivisme, wat aanvoer dat 'werklikheid' deur ons gekonstrueer word en dat skynbaar stabiele, onveranderlike verskynsels eintlik konstrukte is (WIT 2016:81).

Op dieselfde bladsy stel Van Niekerk dat Krog ten spyte van haar ontkenning tog 'onmiskenbaar baie sterk elemente van essensialisering teenwoordig' het 'in haar strewe om "swartheid" te verstaan en aan te prys'. Op die volgende bladsy haal sy Lieskouing aan oor die gegewe dat Krog die 'ganse kontinent in al sy diversiteit en kompleksiteit reduseer tot 'n essensie', 'an unquestionable and abstract entity completely drained of all historical reality' ${ }^{18}$

Van Niekerk argumenteer dat Krog op 'n 'veralgemenende [dit is universele] wyse' op soek is na 'n a-historiese 'abstrakte entiteit' - met name die tydlose skoonheid en uitsonderlikheid van 'swartheid'. Van Niekerk konkludeer:

Soos in hierdie voorbeelde te sien is, is Krog geneig om op veralgemenende wyse met 'Afrika' om te gaan en 'n tydlose essensie en skoonheid daarin te soek. 'Afrika' staan as't ware in vir 'swart', want sy is ten opsigte van 'swart' op soek na skoonheid, tydloosheid en uitsonderlikheid. (WIT 2016:82)

Die wyse waarop Van Niekerk die opvattinge van Krog verstaan, bring haar daartoe om die verwerplike abstrakte, universele, tydlose, onveranderlike essensie ook as die

17.'Die Ordnung und Regelmäßigkeit also an den Erscheinungen, die wir Natur nennen, bringen wir selbst hinein, und würden sie auch nicht darin finden können, hätten wir sie nicht, oder die Natur unseres Gemüts ursprunglich hineingelegt' (Kant 1968:125 - vergelyk ook Kant 1969:163).

18. Krog weerspreek haar hier, want vanuit haar voorkeur vir wording bejeën sy dit wat universeel en konstant is negatief. 
resultaat van 'n 'reïfikasie' te sien. Sy merk krities op dat Krog 'n essensialisering van 'swart' en 'wit' verdedig op grond waarvan Wessels bykomend meen dat 'Krog aktief haar Afrikaneridentiteit van uitwissing wil beskerm' op 'n wyse wat tot 'n reification of ethnicity aanleiding gee (WIT 2016:113).

Ons het gesien dat volgens Van Niekerk 'skynbaar stabiele, onveranderlike verskynsels eintlik konstrukte' is (WIT 2016:81). Hierdie siening is tipies nominalisties want dit stroop die gegewe (ontiese) werklikheid van universaliteit (en konstansie) - en al wat oorbly, is abstrakte denkkonstrukte (universalia post rem in mente humana).

Van Niekerk praat van witheid as konstruk en meen dat ook 'die begrip "swartheid" [...] geen vastigheid [besit] nie'. 'Dit is 'n konstruk, 'n afleiding of sosiale posisie en 'n ideologie. Die inhoud van daardie 'swartheid' is iets waaroor daar voortdurend gesprek gevoer word, anders is dit blatante essensialisering om van "swartheid" te praat' (WIT 2016:21).

\section{Identiteit en transformasie}

Die vraag is natuurlik hoe ' $n$ mens oor identiteit kan praat as jy in jou wysgerige werklikheidsvisie wording (verandering of transformasie) gekies het. Ons het immers gesien dat identiteit verband hou met die funderende samehang tussen die kinematiese aspek van eenparige beweging en die fisiese aspek van energiewerking (verandering). Konstansie en dinamiek is uniek en onherleibaar en hang tegelyk onverbreeklik wederkerig saam. Plato se insig dat in die afwesigheid van iets wat duursaam is, geen kennis van dinge moontlik sal wees nie, hou nog steeds stand ten spyte van die feit dat dit nie nodig is om 'n bo-sinnelike ryk van ewige, statiese ontiese vorms te postuleer nie.

Natuurlik kan enige entiteit in verskeie opsigte ident bly te midde van menigvuldige veranderinge. Met betrekking tot 'n filosofiese nadenke oor 'n gedifferensieerde menslike samelewing, moet in gedagte gehou word dat elke mens 'n veelvoud sosiale funksies kan vervul sonder om ooit in enigeen daarvan op te gaan of volledig deur enigeen daarvan omvat te word. Dit impliseer dat die mens binne elke samelewingsvorm 'n onderskeie gedeeltelike of parsiële identiteit besit. Dit kan 'n gesins- of familie-identiteit wees, of 'n volkskulturele identiteit, of 'n staatkundige identiteit, of 'n genetiese identiteit (DNA-identiteit), of 'n geografiese identiteit (byvoorbeeld alle mense van 'n bepaalde kontinent soos Afrika), en so meer.

Die probleem van die ene en die vele kom ook hier na vore wanneer ons let op watter wyse Van Niekerk die projek van Krog benader. Sy stel dat Krog die stelling verken 'dat "wit" mense kan verander "by integrating several social identities; you are no longer only white, but also South African and African"' (Krog CT 129; WIT 2016:16). 'Several social identities' beteken dat enige mens in verskillende gedifferensieerde samelewingsvorme kan funksioneer, maar dit beteken nie dat hulle geïntegreer of vermeng moet word om 'n gemeenskaplike identiteit te vorm nie. Dieselfde verwarring is in die opmering van Ndlovu-Gatsheni opgesluit dat 'Radical Africanists were of the opinion that citizenship in post-apartheid South Africa was to be rooted in black communal identities, values and virtues' (NdlovuGatsheni 2009:66; WIT 2016:100).

\section{Is Suid-Afrikaans-wees 'n vermenging van identiteite?}

Op hierdie punt word die volgende vraag aktueel: Is SuidAfrikaans-wees 'n vermenging van identiteite - soos wat Krog dit sien? Die verwarring wat hieroor bestaan, verg die opmerkings wat oor burgerskap en oor die plek van die staat in 'n gedifferensieerde samelewing gemaak moet word (paragrawe 'Identiteit en transformasie', 'Wat behels staatkundige burgerskap?' en 'Sosiale omgangsvorme in 'n gedifferensieerde samelewing' van hierdie artikel). Dit geskied teen die agtergrond van die onderskeiding tussen verbands-, gemeenskaps- en maatskapsverhoudinge met verwysing na die klemverskuiwing van dingbegrippe na funksiebegrippe.

Van Niekerk meen dat Country of my skull gelees moet word as 'n teks 'wat die waarheidskommissie sien as 'n belangrike faktor in die totstandkoming van 'n nasionale identiteit wat SuidAfrikaners verenig terwyl hul diversiteit erken word' (WIT 2016:98). Op die volgende bladsy verduidelik sy dat die 'nasionale vraagstuk' soekna'n definisie van 'South Africanness' - 'n soeke wat vir Van Niekerk op 'essensialisering' sal neerkom omdat 'South Africanness' iets (gespesifiseerd) universeel is, soos Aristoteles se bogemelde 'houseness'.

Indien 'n 'nasionale identiteit [...] Suid-Afrikaners verenig terwyl hul diversiteit erken word' (WIT 2016:98), moet besef word dat met die oog op die publiekregtelike aard van burgerskap in die regstaat juis van die diversiteit afgesien moet word. Die staat integreer nie nie-staatlike identiteite nie, maar bloot die regsbelange wat daarin opgesluit lê. Elkeen van hierdie nie-staatlike verbintenisse - soos ouerwees (gesinsidentiteit), eggenoot-wees (huweliksidentiteit), kerklidmaat-wees (geloofsidentiteit), aandeelhouer-wees (sake-ondernemingsidentiteit), student- of dosent-wees (akademiese identiteit) - herberg bepaalde regsbelange wat in die regsverkeer geskend kan word en wat dan op beregting deur die toepaslike staatlike regsorgane (bv. die strafhof of die siviele hof) aangewese is.

\section{Die regsbelange van nie-staatlike identiteite}

Die owerheid van 'n burgerstaat (regstaat) is immers daartoe geroepe om af te sien van die nie-staatlike verbintenisse van die burgery sodat effektief juridies omgesien kan word na die regsbelange wat in daardie verbintenisse opgesluit lê. Die veronderstelling is dat die staat nie onregmatig in die interne regsfere van die nie-staatlike samelewingsvorme mag inmeng nie. Geen sosiale vereniging, ekonomiese onderneming, huwelik, gesin, familie of geloofsgenootskap is tewens ' $n$ deel van die staat as vermeende allesomvattende 
samelewingsgeheel nie. Elke lewensvorm in 'n gedifferensieerde samelewing beskik oor ' $n$ aardeie bevoegdheidsfeer, wat ook as die soewereiniteit-in-eie-kring daarvan beskryf kan word.

Die sosiale inhoud wat aan 'witheid' en 'swartheid' gegee word, wissel met die verloop van tyd en op verskillende plekke. Insoverre 'n bepaalde definisie op 'n gegewe tydstip aanvaarbaar gevind word, is dit so omdat (implisiet of eksplisiet) geappelleer word op die kondisies vir (orde vir) swartwees of witwees. Die kondisies (wet vir) swartwees of witwees is weliswaar nie self swart of wit nie, net so min as wat die kondisies vir atoomwees self ' $n$ atoom is. Binne ' $n$ sosiale konteks moet uiteraard eers vasgestel word of daar 'n tipe-wet is wat ' $n$ bepaalde klas van mense (swart of wit) omvat.

\section{(On)gespesifiseerde universaliteit}

Die idee van die orde vir entiteite kan tewens op twee verskillende wyses gebruik word: in die sin van modale universaliteit en tipiese universaliteit. Modale (aspek-) wette is ongespesifiseerd universeel want dit het betrekking op alle moontlike (klasse van) entiteite. Die swaartekragwet of die hoofwette van die termodinamika geld vir alle klasse van fisiese entiteite. Die tipe-wet vir atoomwees daarenteen het alleen op ' $n$ beperkte klas van entiteite betrekking. Tipe-wette is nog steeds universeel, maar in 'n gespesifiseerde sin. Die wet vir atome is universeel in die sin dat dit vir alle atome geld, maar dit is gespesifiseerd deurdat dit slegs vir'n bepaalde tipe entiteit geld, naamlik atome.

Wanneer dit blyk dat die sosiale inhoud wat aan 'witheid' en 'swartheid' in 'n bepaalde samelewing gegee word, sterk kan wissel, hoef die realiteit van universele kenmerke nie bevraagteken te word nie. As die 'Freedom Charter' stel dat 'South Africa belongs to all who live in it, black and white' (vergelyk Van Niekerk WIT 2016:99), dui dit op die insluiting van alle Suid-Afrikaners afgesien van witwees of swartwees.

Die verwarring van nie-staatlike identiteite en die regsbelange wat daarin opgesluit lê, kom duidelik ook in die gedagtegang van Bundy (2007:80) na vore wanneer hy stel: 'Die "Reënboognasie" was uiteraard 'n poging om die moontlikheid van ' $n$ harmonieuse, gemeenskaplike identiteit te verklaar hoewel daardie identiteit uit verskillende "kleure" ("rasse" of "kulture") sou bestaan' (WIT:101) - wat eintlik handel oor die 'soeke na 'n gemeenskaplike Suid-Afrikaanse identiteit' (Bundy 2007:82; WIT:101).

\section{Wat behels staatkundige burgerskap?}

Burgerskap konstitueer per definisie'n persoon se staatkundige identiteit (waar so 'n person leef, werk en woon) - maar dit vra nie aan watter ras of godsdienstige denominasie 'n persoon behoort nie, wat die sosiale stand van so 'n persoon is nie, of ' $n$ persoon ryk of arm is nie, aan watter kultuurgemeenskap (volk) so 'n persoon behoort nie, of die geslag van die persoon manlik of vroulik is nie, ensovoorts. Die vraag na burgerskap sien dus van alle nie-staatlike lewensverbintenisse af - hoeseer dergelike verbintenisse wel 'n rol in die verkryging van burgerskap kan speel. Burgerskap dui onder meer op afstamming (is die betrokke persoon se ouers burgers) of op geboorte (is die persoon op die territorium van die betrokke staat gebore).

\section{Sosiale omgangsvorme in 'n gedifferensieerde samelewing}

'n Debat oor die aard van die moderne staat (kyk Strauss 2016) moet allereers geskied. Aan die hand van twee definiërende kenmerke kan dan tussen drie verskillende wyses van omgang en verkeer in 'n gedifferensieerde samelewing onderskei word: (1) 'n solidêre eenheidskarakter (wat impliseer dat 'n samelewingsvorm ongeag die wisseling van die individuele lede daarvan voortbestaan), en (2)'n permanente gesagstruktuur ('n duursame relasie van bowe- en onderskikking). Wanneer beide kenmerke aanwesig is, ontmoet ons verbande (soos die staat, bedryf, gesin, skole en universiteite); wanneer slegs een aanwesig is, onderken ons gemeenskappe (die familie, huwelik en volk - lg. as kultuurgemeenskap). In die derde plek besit maatskapsverhoudinge geeneen van hierdie twee eienskappe nie (vriendskap, buurskap, en so meer).

Die burgerlike privaatreg omvat neweskikkende regsverhoudinge waarin individue en instansies op gelyke voet naas en selfs teenoor mekaar te staan kom. Gevolglik is die burgerlike privaatreg gekorrelleer sowel met die nie-burgerlike privaatreg as met die publieke reg van die staat. Die nie-burgerlike privaatreg omvat die interne reg van die nie-staatlike samelewingsvorme soos die sake-onderneming, huwelik, gesin, sosiale verenigings, geloofsdenominasies, opvoedkundige en akademiese instellings, en so meer. Ongeskonde samelewingsvryhede vorm die hoeksteen van 'n gedifferensieerde samelewing. Met burgerskap wat ons staatkundige identiteit konstitueer, is dit gebruiklik om tussen volk en nasie te onderskei. Die staatkundige nasie laat volledig ruimte vir meerdere volke op sy territorium. ${ }^{19}$

Beide die burgerlike privaatreg en die publiekregtelike aard van die staat besit ' $n$ tipiese juridiese stempel. ' $n$ Egte staat is immers nodig om die eiendom en liggaamlike integriteit van die burgery te beskerm en om burgerlike geskille deur onpartydige siviele regspraak (jurisprudensie) te besleg en die vonnisse daarvan amptelik ten uitvoer te bring. Die sfeer van die burgerlike privaatreg beskerm die juridiese persoonlikheidswaarde van die individuele mens afgesien van die veelheid sosiaal gedifferensieerde verbintenisse waaraan die mens deel kan hêwat kan vertak in standverskille, taalverskille, rasverskille, geloofsverskille, ekonomiese verskille, sosiale verskille, verskille in begaafdheid, en so meer. Hierdie regsgebied word soms ook as common law aangedui, gerugsteun deur die bypassende beginsels van natuurlike geregtigheid. In die nie-staatlike lewensvorme tree die mens daarenteen as lid van 'n groter geheel op en nie bloot as 'n private enkeling nie.

Die aard van die burgerlike privaatreg is geensins individualisties nie. Inteendeel, alle verbands- en gemeenskapsverhoudinge is

19.Van Niekerk se bewering dat tot "1994 [...] die konsep van "nasie" nie werklik bestaan [het] in Suid-Afrika nie,' is histories onjuis. (WIT 2016:20). 
deurlopend onverbreeklik met maatskapsverhoudinge gekorrelleer - en omgekeerd. 'n Individualistiese benadering verabsoluteer maatskapsverhoudinge (ten koste van gemeenskaps- en verbandsverhoudinge), terwyl universalistiese benaderings gemeenskaps- en verbandsverhoudinge verabsoluteer ten koste van maatskapsverhoudinge.

Die onderskeiding tussen maatskapsverhoudinge enersyds en gemeenskaps- en verbandsverhoudinge andersyds behels 'n strukturele en nie 'n genetiese (historiese) onderskeiding nie. Daarom is dit problematies dat Krog die beweging vanuit landelike gebiede na die stede op 'n wyse skets soortgelyk aan wat in Tönnies se 1887-werk, Gemeinschaft und Gesellschaft, te vinde is. Dit behels ' $\mathrm{n}$ genetiese oorgang van tight interconnected groups na 'n situasie waarin hulle 'gedwing [word] om as individue te funksioneer' (WIT 2016:32).

Ewe problematies is Van Niekerk se aanhaling van Robinson en Torney (2010) in verband met 'nondenumerability':

A minority is defined not by its expression of the process of becoming (rather the fixity of being), and by the gap of its situation from the majority axiom or benchmark [...] By the nondenumerable, qualitative process of becoming, it threatens to destroy the very concept of majority. (bl. 23-24; WIT 2016:27)

Bricmont en Sokal het 'n werk geskryf oor die wyse waarop postmoderne denkers die wetenskappe misbruik. In hierdie werk kom Deleuze en Guattari ook aan die beurt (Sokal \& Bricmont 1999:177-192). Aan die voorbeelde wat hulle vermeld, kan hierdie verwysing na nie-aftelbaarheid toegevoeg word. Hoewel Cantor self, as grondlegger van die moderne wiskundige versamelingsleer, van mening was dat die fisiese heelal aktueel oneindig is, is die fisiese werklikheid bloot aftelbaar oneindig. ${ }^{20}$

Sedert die Renaissance is die wysgerige klem op substansie (ding) geleidelik deur funksie- of relasiebegrippe vervang (kyk Strauss 2011b). Hierdie klemverskuiwing van ding na relasie het ons kultuur tot so 'n mate deursuur dat dit vandag selfs in advertensies opduik. Op CNN (26-02-2018 - 23:00) verklaar 'n Guinness Advertensie: 'All Things Relationships'; en op die Supersport Kanaal van DStv (Kanaal 206 - 13-032018) verklaar Auto trader: 'It is more than some machine, it is a relationship'.

Sonder om in verdere besonderhede daarop in te gaan, moet in hierdie konteks ook daarop gewys word dat die kontrastering van die Europese en Afrika-kulture vanuit 'n historiese samelewingsperspektief gesien, problematies is. Die tradisionele samelewings wat reeds voor maar ook na die begin van ons jaartelling in Europa en die Britse eilande aangetref word, besit dieselfde ongedifferensieerde struktuur as die stamkulture van (Suid-)Afrika (dink aan die Germaanse stamme wat die Romeinse ryk oorspoel het). Dergelike samelewings is in een totaalstruktuur saamgesnoer. Sulke samelewings besit' $n$ ongedifferensieerde fundering (slegs een organisasievorm vir alle lewensaktiwiteite) asook in ongedifferensieerde kwalifisering - die geheel besit 'n kokonstruktuur wat as geheel telkens in verskillende hoedanighede optree, hetsy as 'n boerdery- of jaggemeenskap, as 'n kultiesgodsdientige eenheid of as 'n politieke entiteit. Die grootfamilie en sib (of clan) word deur die familiestruktuur gelei en die sterker georganiseerde stamverband deur die politieke struktuur. Namate tradisionele samelewings ontwikkel en differensieer, sien ons eventueel hoedat vanuit die kokonstruktuur selfstandige samelewingsvorme na vore tree - soos die kerk, die staat, die bedryf, die huisgesin en skole en universiteite - elkeen gerig deur 'n eenduidige modale aspek en nie deur een of ander vervlegte struktuur nie (die staatsverband deur die regsaspek, die bedryf deur die ekonomiese aspek, 'n geloofsverband deur die geloofsaspek, 'n huweliksgemeenskap deur die etiese aspek, en so meer).

Hoewel Goosen en Malan dieselfde universalistiese waardering van die 'geheel' het as Krog, staan hulle in die praktiese politiek diametraal teenoor mekaar. Die opvattinge van Goosen en Malan word elders uitvoerig deur Strauss (sien 2017a; 2017b; 2017c; 2018) bespreek. Sien ook Bylaag 1.

\section{Slotsom}

In die bostaande is ruim aandag bestee aan Krog se omgang met die Suid-Afrikaanse werklikheid; die verlede, hede en ook 'n toekomsperspektief wat deur 'n bepaalde ideologiese en filosofiese invalshoek gerig word. Hoewel Jacomien van Niekerk waardering verdien vir haar wye leeswerk, plek-plek indringende analises en in teoretiese fundering, is ons slotsom dat veral die eensydige ideologiese perspektief van Krog (én meestal ook van Van Niekerk) tot in wetenskaplike eensydigheid lei. Dit geld kernaspekte van die denke van Krog én dikwels die evaluering daarvan deur Van Niekerk. In die inleidende gedeelte is na 'n groep jonger literatore, hulle gemeenskaplike benadering, én die (wetenskaplike) wins daarvan verwys. Tog moet daar ook in paar bedenkinge genoem word. Hulle raak dikwels so meegevoer met veral ideologiese argumente dat dit tot die uiterste (en selfs) absurde gevoer word.'n Soortgelyke vereenvoudigende veralgemening is die stelling dat 'alle mense eintlik diere is - gefokus op hulle eie oorlewing' (bl. 124). Ten spyte van die gegewe dat die (neo-)Darwinisme hierdie oortuiging kontinueer, moes selfs leidinggewende denkers uit hierdie tradisie toegee dat daar'n absolute tipe-verskil tussen dier en mens is:

Man has certain basic diagnostic features which set him off most sharply from any other animal and which have involved other developments not only increasing this sharp distinction but also making it an absolute difference in kind and not only a relative difference of degree. (Simpson 1971:270)

Portmann tipeer die dier as instink-versekerd en milieugebonde en die mens as instrink-vry en 'Weltoffen' (oop na die wêreld - Portmann 1990:79). Gould (1992) onderskei die mens se pontensialiteit van genetiese determinisme (Dawkins se 'selfish gene'). Gould wys die volgende uitspraak van Wolfgang Wickler af: 'It follows from evolutionary theory that the genes run the individual in their own interest'. Gould se reaksie is 
radikaal: 'I confess I cannot regard such a statement as much more than metaphorical nonsense' (Gould 1992:269).

Habermas verwys ook na die heersende naturalistiese determinisme en merk dan op dat hierdie siening die vryheid van die menslike wil as skyn verstaan waaragter die wette van die natuur alles beheers. Dan vra hy die vraag:

But does the deterministic conception represent a thesis with a natural scientific foundation at all, or does it simply form part of a naturalistic world view resulting from a speculative interpretation of natural scientific knowledge? (Habermas 2005:156)

Habermas (2001) se non-reduksionistiese sentimente is duidelik wanneer hy opmerk:

The scientistic belief in a science which one day in the future not only will broaden our personal selfunderstanding, but through an objectifying self-description will also eliminate it, is not science but bad philosophy. (bl. 20)

Dat 'n relatief dun boek van Van Niekerk die ondersoekers genoop het om fundamentele vrae te probeer beantwoord, is bewys genoeg dat dit inderdaad ' $n$ waardevolle studie is. Enige wetenskaplike ondersoek is in wese tog net nog 'n verdere bousteen of onderdeel van 'n gesprek sonder einde.

Deur te erken dat met die probleme wat aan die orde gestel word ten diepste op die gebied van die filosofie beweeg word, bevat die werk van Van Niekerk 'n openlike uitnodiging aan filosowe om na te gaan hoe suksesvol (of relatief gebrekkig) met hierdie wysgerige probleme omgegaan is. Daarom het hierdie ondersoek grootliks die laaste deel van hierdie artikel in beslag geneem.

\section{Erkenning Mededingende belange}

Die outeurs verklaar dat hulle geen finansiële of persoonlike verbintenis met enige party wat hulle nadelig of voordelig kon beïnvloed het in die skryf van hierdie artikel nie.

\section{Outeursbydrae}

D.F.M.S. was verantwoordelik vir die paragrawe vanaf 'Krog en die Afrikafilosofie' tot en met 'Sosiale omgangsvorme in 'n gedifferensieerde samelewing'. H.P.v.C. was verantwoordelik vir die res van die artikel.

\section{Literatuurverwysings}

Althusius, J., 1614 [1603], Politica methodice digesta [Collection of systematic political views], 3rd edn., The politics of Johannes Althusius; ' $n$ Verkorte vertaling van die derde uitgawe van Politica methodice digesta, atque exemplis sacris et profanis illustrata/Althusius, Johannes; vert. met ' $n$ inleiding deur Frederick S. Carney, 1965, London: Eyre \& Spottiswoode. Kyk ook na die volledige vertaling. Althusius, J., 1979, Politica methodice digesta of Johannes Althusius (Althaus), met 'n inleiding deur Carl Joachim Friedrich, Arno Press, New York.

Aristoteles, 1894, Politica, Teks uitgawe deur F. Susemihl \& R.D. Hicks: The politics of Aristotle, Hers, teks, McMillan, New York.

Aristoteles, 2001 [1941], The basic works of Aristotle, R. McKeon (ed.) with an introd. by C.D.C. Reeve (Originally published by Random House), The Modern Library, New York.

Brewster, L.M. \& Seedat, Y.K., 2013, 'Why do hypertensive patients of African anchestry respond better to calcium blockers and diuretics than to ACE inhibitors and $\beta$-adrenergic blockers? A Systematic Review', BMC Medicine 11(141). https:// doi.org/10.1186/1741-7015-11-141
Brewster, L.M., Van Montfrans, J. \& Kleijnen, J., 2004, 'Systematic review: Antihypertensive drug therapy in black patients', Annals of Internal Medicine 141(8), Antihypertensive drug therapy in black patients', Annals of Internal Medicin

Bundy, Colin, 2007, 'New nation, new history? Constructing the past in post Apartheid South Africa', in H.E. Stolten (ed.), History making and present day politics: The meaning of collective memory in South Africa, pp. 73-97, Nordiska Afrikainstitutet, meaning
Uppsala.

Burroughs, V.J., Maxey, R.W. \& Levy, R.A., 2002, 'Racial and ethnic differences in response to medicines: Towards individualized pharmaceutical treatment', Journal of the National Medical Association

Coetzee, J.M., 1999, Disgrace, Vintage Afrikaans trans. Fanie Olivier (2009), London.

Descartes, R., 1965, 'The principles of philosophy', in A discourse on method, meditations and principles, transl. J. Veitch, introd. A.D. Lindsay, Everyman's Library, London.

Diels, H. \& Kranz, W., 1959-1960, Die Fragmente der Vorsokratiker, Vols. I-III, Weidmannsche Verlagsbuchhandlung, Berlin.

Fowler, D., 1999, The mathematics of Plato's academy, 2nd edn., Clarendon, Oxford.

Galileo, G., 1914 [1638], Dialogues concerning two new sciences, trans. Henry Crew \& Alfonso de Salvio, Dover publications, New York.

Garman, A., 2015, Antjie Krog and the post-apartheid public sphere: Speaking poetry to power, UKZN Press, Pietermaritzburg.

Gould, S.J., 1992, Reflections in natural history: Ever since Darwin, Norton, New York. Habermas, J., 2001, Glauben und Wissen, Suhrkamp, Frankfurt am Main.

Habermas, J., 2005, Zwischen Naturalismus und Religion, Suhrkamp, Frankfurt am Main.

Hall, S., 1990, 'Cultural identity and diaspora in J. Rutherford, Community, culture, difference, pp. 222-237, Lawrence \& Wishart, London.

Hambidge, J., 2015, Perspektief en profiel, H.P. van Coller, Deel 1, geraadpleeg 03 Februarie 2017, by http://joanhambidge.blogspot.co.za/search/label/Perspektief $\% 20 \%$ en\%20Profie

Happ, H., 1971, Hylè, Studien zum aristotelischen Materie-Begriff, De Gruyter, Berlin. Hegel, G.W.F., 1807, Phänomenologie des Geistes, Verlag von Felix Meiner, Hamburg. Janich, P., 1975, 'Tragheitsgesetz und Inertialsysteem', in Chr. Thiel (Ed.), Frege und die moderne Grundlagenforschung, pp. 64-85, Hain, Meisenheim am Glan.

Janich, P., 2009, Kein neues Menschenbild: Zur Sprache der Hirnforschung, Suhrkamp, Frankfurt am Main.

Kant, I., 1956 [1781], Kritik der reinen Vernunft, 1st edn. (ref. to CPR A), Felix Meiner, Hamburg.

Kant, I., 1956 [1787], Kritik der reinen Vernunft, 2nd edn., (references to CPR B), Felix Meiner, Hamburg.

Kant, I., 1969 [1783], Prolegomena zu einer jeden künftigen Metaphysik die als Wissenschaft wird auftreten können, Felix Meiner Hamburg.

Krog, A., 1995, 'The South African road', in A. Boraine \& J. Levy (eds.), The healing of a nation?, pp. 112-119, Justice in Transition, Cape Town.

Krog, A., 2008, “This thing called Reconciliation": Forgiveness as part of an interconnectedness-towards-wholeness', South African Journal of Philosophy 27(4), 353-366. https://doi.org/10.4314/sajpem.v27i4.31524

Longo, G., 2001, The mathematical Continuum: From intuition to logic, viewed 19 October 2010, from ftp://ftp.di.ens.fr/pub/users/longo/PhilosophyAndCognition/ the-continuum.pdf

Louw, N.P. v W., 1939a, Lojale verset, Nasionale Pers, Kaapstad.

Louw, N.P. $\vee$ W., 1939b, Berigte te velde: Opstelle oor die idee van 'n Afrikaanse nasionale letterkunde, Van Schaik, Pretoria.

Luckmann, T. \& Berger, P.L., 1969, The social construction of reality; A treatise in the sociology of knowledge, Allen Lane, London.

McGonegal, J., 2009, 'Imagining justice: The politics of postcolonial forgiveness and reconciliation', McGill University Press, Montréa1.

Munson, R. (ed.), 1971, Man and nature: Philosophical issues in biology, Dell, New York.

Ndlovu-Gatsheni, S.J., 2009, 'Africa for Africans; or Africa for "Natives only"? New Nationalism \& Nativism in Zimbabwe and South Africa', Africa Spectrum 44(1), 61-87.

Olthuis, J.H. (ed.), 1997, Knowing other-wise: Philosophy at the threshold of spirituality, Fordham University Press, New York.

Planck, M., 1910, 'Die Stellung der neueren Physik zur mechanischen Naturanschauung', Vortrag gehalten am 23. September 1910 auf der 82. Versammlung Deutscher Naturforscher und Ärzte in Königsberg i. Pr.

Planck, M., 1973, Vorträge und Erinnerungen, 5. Ausg., Wissenschaftliche Buchgesellschaft, Darmstadt.

Plato, 1973, The collected dialogues of Plato; including the letters, eds. E. Hamilton \& C. Huntington, University Press, Princeton, NJ.

Portmann, A., 1990, A zoologist looks at humankind, trans. Judith Schaefer, Columbia University Press, New York.

Renders, L., 2012, 'Op zoek naar Afrika: Over Begging to be black van Antjie Krog en andere recent verschenen autobiographische teksten van Afrikaanse auteurs', Werkwinkel 7(1), 73-95.

Riedweg, C., 2005, Pythagoras: His life, teaching, and influence, Cornell University Press, Ithaca, NY. 
Russell, B., 1956 [1903], The principles of mathematics, Allen \& Unwin, London.

Schrödinger, E., 1955, What is life? The physical aspect of the living cell, Cambridge UniversityPress, Cambridge.

Schutz, H., 1974 [1932], Der sinnhafte Aufbau der sozialen Welt, Springer Verlag, Suhrkamp, Frankfurt am Main.

Simpson, G.G., 1971, 'Man's place in nature', Section from 'The meaning of evolution', incorporated in Munston 1971, pp. 4-16, Yale University, Munson.

Sokal, S. \& Bricmont, J., 1998, Fashionable nonsense: Postmodern intellectuals' abuse of science, Picador, New York. (cf. the German edition: Eleganter unsinn: Wie die Denker der postmoderne die Wissenschaften missbrauchen, Beck, München.)

Strang, C. \& Mills, K.W., 1974, 'Plato and the instant', Aristotelian Society Supplementary Volume 48(1), 63-96. https://doi.org/10.1093/aristoteliansupp/48.1.63

Strauss, D.F.M., 2004, “"Eat it again for the first time": Identity in a world of change', Koers 69(4), 555-574. https://doi.org/10.4102/koers.v69i4.317

Strauss, D.F.M., 2009, Philosophy: Discipline of the disciplines, Paideia Press, Grand Rapids, MI.

Strauss, D.F.M., 2011a, '(Oor)aftelbaaarheid', Koers 76(4), 637-659. https://doi. org/10.4102/koers.v76i4.414

Strauss, D.F.M., 2011b, 'Relasiebegrippe in die lig van die vraag of Einstein in die eerste plek 'n "relatiwiteitsteorie" ontwikkel het', Suid-Afrikaanse Tydskrif vir
Natuurwetenskap en Tegnologie 30(1). Art. \#28, 1-8. https://doi.org/10.4102/ satnt.v30i1.28

Strauss, D.F.M., 2013, 'Einstein se relatiwiteitsteorie: Op die kruispunt van aprioriese elemente en empiriese ervaring', Suid-Afrikaanse Tydskrif vir Natuurwetenskap en Tegnologie 32(1), Art. \#329, 8 pages. http://dx.doi.org/10.4102/satnt.v32i1.329

Strauss, D.F.M., 2016, 'Die debat oor die moderne staat/The debate on the modern state', September 2016, Tydskrif vir Geesteswetenskappe 56(3), 876-880. https:// doi.org/10.17159/2224-7912/2016/v56n3a10

Strauss, D.F.M., 2017a, 'Besinning oor staat en samelewing/Reflecting on state and society', Junie 2017, Tydskrif vir Geesteswetenskappe 57(2-2), 668-679. https:// doi.org/10.17159/2224-7912/2017/v57n2-2a11

Strauss, D.F.M., 2017b, 'Wysgerige onderskeidinge relevant vir ' $n$ besinning oor staat en samelewing met besondere verwysing na Koos Malan se Politokrasie', September 2017, Tydskrif vir Geesteswetenskappe 57(3), 852-869. https://doi. org/10.17159/2224-7912/2017/v57n3a13

Strauss, D.F.M., 2017c, 'Die aard en plek van die geheel-dele-relasie - gesien vanuit ' $n$ algemeen-wysgerige sowel as ' $n$ vakfilosofiese perspektief/The nature and place of of the philosophy of the special sciences', Des 2017, Tydskrif vir Geesteswetenskappe 57(4), 1078-1092. https://doi.org/10.17159/2224-7912/2017/v57n4a14

Strauss, D.F.M., 2018, 'Gemeenskappe in 'n gedifferensieerde samelewing', Tydskrif vir Geesteswetenskappe 2018, 58(1). https://doi.org/10.17159/2224-7912/2018/v58n1a
Taljaard, M., 2010, 'Kleur hibried: Kleur kom nooit alleen nie en die talige ruimte van saambestaan', LitNet Akademies 7(3).

Tantrigoda, P., 2016, 'Body as a site of justice and expiation in J.M. Coetzee's fiction', Postcolonial Text 11(4), 1-17.

Ter Horst, G., 2008, De Ontbinding van de substantie: Een deconstructie van de beginselen van vorm en materie in de ontologie en de kenleer van Thomas Aquinas., Delft: Uitgeverij, Eburon.

Van Coller, H.P., 1997, 'Die waarheidskommissie in die Afrikaanse letterkunde: Die Afrikaanse prosa in die jare negentig', Stilet 9(2), 9-21.

Van Coller, H.P. \& Odendaal, B.J., 2003a, 'Kleur kom nooit alleen nie (Antjie Krog) en Die burg van Hertog Bloubaard (H.J. Pieterse): 'n poëtikale beskouing', Deel 1 Stilet 15(1), 16-35.

Van Coller, H.P. \& Odendaal, B.J., 2003b, 'Kleur kom nooit alleen nie (Antjie Krog) en Die burg van Hertog Bloubaard (H.J. Pieterse): 'n poëtikale beskouing', Deel 2 Stilet 15(1), 36-64.

Van Coller, H.P. \& Odendaal, B.J., 2007, 'Antjie Krog's role as translator: A case study of strategic positioning in the current South African literary poly-system, Current Writing 19(2), 94-12

Van Niekerk, J., 2013, 'Winterbach en die Groot Afrikaanse Roman (wedstryd), 'Resensie-essay van Die aanspraak van lewende wesens deur Ingrid Winterbach', SlipNet, posted on 11 April 2013.

Van Niekerk, J., 2016, 'baie worde': Identiteit en transformasie by Antjie Krog [WIT], Van Schaik, Pretoria.

Wang, J., 2009, 'White postcolonial guilt in Doris Lessing's The grass is singing', Research in African Literatures 40(3), 37-47. https://doi.org/10.2979/ RAL.2009.40.3.37

Willoughby-Herald, T., 2014a, 'Fighting for an intervention in history in the face of dreams deferred in the making: Twenty years of South African democracy', African Identities 12(3-4), 225-235. https://doi.org/10.1080/14725843.2015 1009615

Willoughby-Herald, T. 2014b, 'Black rainbows: Militant white women writers, postracial discourse, and the stakes of race, class, and gender in South Africa', Journal of Contemporary Thought 39, 197-218.

Willoughby-Herald, T., 2014c, 'Mammy no more/Mammy forever: The stakes and costs of teaching our colleagues', in S. Fryberg \& E.Martinez (eds.), The truly diverse faculty, pp. 157-200, Macmillan, Palgrave.

Willoughby-Herald, T., 2015, 'The secret eye: Black women in politics and publishing. Broadening the contours in the study of black politics: Political development and black women', National Political Science Review 17(1), 75-82.

Wittgenstein, L., [1921] 1966, Tractatus logico-philosophicus, 3rd edn., Routledge \& Kegan Paul, London. 


\section{Bylaag 1 \\ Teksversorging}

Daar is reeds vermeld dat Hein Willemse opgetree het as 'persklaarmaker' of redigeerder, 'die taalkundige wat finale verbeterings aan ' $n$ teks aanbring', aldus die 2015-HAT.

Daar val nogal veel aan te merk oor die styl van hierdie boek wat dikwels lomp, anglisisties en hoogdrawend (deftig) is. Die volgende opname toon iets hiervan:

- 9: 'Enersyds skryf sy vanuit haar posisie van haar Afrikanerskap [...] en stel die vraag van wie hierdie identiteit(e) mag aanneem.'

- 11. 'valorisering': eerder 'waardering' of 'valorisasie'.

- 15: 'preokkupasies'

- 16: 'Wanneer sy in Engels skryf, eweneens, 'ondermyn sy [...]'

- 'maar beteken dit sy is dié 'getransformeerde Afrikaner' [...] wat instaan vir soortgelyke persone?

- Perform sy haar medepligtigheid, skuldgevoel en intense begeerte tot verstaan van die Ander in die openbaar omdat dit 'for the emulation of others' [...] bedoel is?'

- $17:$ 'sy bevoorgrond die kontras tussen haar eie stem ...'

- 19: 'uitsorteer' verdien 'n 'sic!'.

- 'preokkupasies', 'reduseer'.

- 'waarheidskommissie' moet wees Waarheids-en-versoeningskommissie.

- 20: 'kliewende selfondersoek'.

- 23: 'kliewende selfondersoek'.

- 27: 'konneksie' eerder as 'verbinding'; 'ruptuur' eerder as 'breuk'.

- 29: 'Tog voer sy aan dat sy nie vernaam ...'.

- 32: 'interkonneksie'.

- 34: 'om gekonnekteer [sic] te wees met ...'

- 58: 'vertalling van sy lewensverhaal' moet lees 'vertaling van sy lewensverhaal'.

- : 'om van Mandela se besluit te maak'; eerder: 'van Mandela se besluit af te lei'.

- 59: 'terwyl dié bewondering nie aan die res [...] geskenk word nie.'

- : 'Wanneer Krog dit prosesseer' eerder as 'verwerk'?

- 65: 'interkonneksie'

- 67: 'Afrikafilosofie is bruikbaar vir die gebaar wat Krog uitvoer'.

- 76: 'gebaar uitvoer'.

- 77: 'gebare wat Krog uitvoer'.

- 96: 'kyk en observeer'. Waarom nie 'waarneem' nie?

- 80: 'interkonneksie'

- 81: 'valorisering'.

- 88: 'Nie net word sekere antwoorde tydens die waarheidskommissie-verhore verskaf tot ... die moord ...'

- 92: 'wat die etiket van "slagoffers" omhels ...'

- 94: 'quasi' moet lees 'kwasi'.

- 96: 'Afrika-interkonneksie'.

- 97: 'Heelwat voorbeeld van ná-1994 retoriek' moet lees 'Heelwat voorbeelde van ...'.

- 107/108: 'interkonneksie', 'koherensie', 'omhelsing van 'n Afrikawêreldbeeld'.

- 113: 'kosmpolitanisme' moet lees 'kosmopolitiese' of 'kosmopolitisme'.

- 115: 'Sy nooi [sic] 'n "swart" perspektief op haarself as "wit" en westers uit ...'.

- 117: 'konstante wording te omhels'.

- 118: 'Krog se hele oeuvre tot op datum [...] met die oeuvre van Krog ...' 